\title{
Anomalous enrichment of molybdenum and associated metals in Lower Jurassic (Lias Group) black shales of central England, as revealed by systematic geochemical surveys.
}

\author{
N Breward ${ }^{\#}$, S J Kemp*, K Ambrose, J H Powell, A Morigi ${ }^{\dagger}$ and D Wagner \\ British Geological Survey, Keyworth, Nottingham, NG12 5GG, UK \\ \#8 Charnwood Avenue, Keyworth, Nottingham NG12 5JX, UK \\ ${ }^{\dagger} 5$ Harby Lane, Plungar, Nottingham, NG13 OJH, UK \\ *Corresponding author: sjk@bgs.ac.uk
}

\begin{abstract}
Systematic multi-media geochemical surveying by the British Geological Survey's Geochemical Baseline Survey of the Environment (G-BASE) project has revealed significant anomalous patterns of enrichment for a suite of elements - copper $(\mathrm{Cu})$ and uranium (U) - with exceptionally high levels of molybdenum (Mo), in soils and stream sediments in central England. Enrichment of these elements is most often associated with organic-rich, sulphidic 'black shale' lithofacies, typical of oxygendeficient, euxinic depositional environments. The main anomaly lies between Evesham and Rugby where the bedrock comprises the Blue Lias and Charmouth Mudstone formations. Concentrations of Mo are particularly high, reaching soil values of $50 \mathrm{mg} / \mathrm{kg}$, where the regional background is $<2 \mathrm{mg} / \mathrm{kg}$. Analysis of black shale partings sampled from rhythmic limestone-shale couplets reveal Mo levels up to $320 \mathrm{mg} / \mathrm{kg}$. Complementary X-ray diffraction analyses suggest that the anomalous Mo levels are hosted by sulphidic (pyrite) rather than organic phases. High Mo levels
\end{abstract}


may have significant impacts on local agriculture, as well as revealing hitherto unsuspected periods of hypoxic and anoxic bottom water sedimentation within localised basins in the central England during the Early Jurassic. Rhythmic alternations of thin beds of Mo-rich, sulphidic black shale (euxinic) with bioclastic and micritic limestone (oxic) represent primary depositional cycles rather than a diagenetic origin. The bed-scale cyclicity is attributed to previously described orbitally-induced precession cycles that influenced climate. These resulted in periods of basin anoxia and black shale sedimentation during periods of enhanced terrestrial fresh-water run-off (possibly below a low-salinity pycnocline), alternating with periods of oxygenation of the sea-water and bottom sediments during overturn of the water column.

Keywords: molybdenum; Lias Group cycles; geochemical survey; mineralogy; pyrite; black shale 


\section{Introduction}

Regional geochemical surveys carried out by the British Geological Survey’s Geochemical Baseline Survey of the Environment (G-BASE) project have been carried out systematically over much of the British Isles (Johnson and Breward, 2004; Johnson et al., 2005; Simpson et al., 1996). In the English Midlands (Figure 1a), soil sampled at two depths on a $2 \mathrm{~km}$ grid basis during 1997-1999 has revealed anomalously high levels of enrichment for a suite of metals - molybdenum (Mo), copper (Cu) and uranium (U) - with Mo showing exceptionally high levels over a NNE-trending outcrop of Lower Jurassic bedrock (Hettangian to Lower Sinemurian age) comprising the Blue Lias Formation and the lower part of the overlying Charmouth Mudstone formations (Lias Group). This anomaly (Figure 1b) extends from near Rugby at least as far south-west as Evesham, and probably beyond. However, the Mo anomaly does not apparently extend to the Lower Jurassic rocks of the Dorset coast (Rawlins et al., 2012) where uranium- and thorium-rich black shales have been reported from coeval rocks (Bessa and Hesselbo, 1997; Jenkyns et al., 2002), or northwards into Leicestershire Nottinghamshire and Lincolnshire. Sequences of Lower Jurassic organic-rich black shales are commonly associated with thin inter-beds of limestone and have been shown to have enhanced levels of the metals uranium, thorium and vanadium (Bessa and Hesselbo, 1997). These metals and their corresponding gamma-ray levels revealed in borehole wireline logs reach their highest levels in the laminated dark shale and dark marl beds (Whittaker et al., 1985; Ivimey-Cook and Powell, 1991; Van Buchem et al., 1992; Jenkyns et al., 2002). 
The origin of Lower Jurassic sequences comprising alternating limestone and black shale in southern and south-west England has been the subject of debate (Hallam, 1957, 1960; 1986; Raiswell, 1988; Bottrell and Raiswell, 1989; Weedon, 1986; Smith 1989; Hesselbo et al., 2004; Radley, 2008; Ruhl et al., 2010). It is generally accepted that these sediments were deposited at low latitudes in a shallow epeiric sea (i.e. extending inland) in connection with the Tethys Ocean (Donovan, 1992). Early hypotheses attributed the regular limestone - black shale couplets are the result of diagenesis of an original homogeneous lime mud (Hallam, 1986; Arzani, 2004). However, it is now generally accepted that diagenetic processes have only enhanced original environmentally-controlled alternations of lime-rich (micrite to wackestone) and lime-poor (organic-rich siliciclastic mud) couplets, the latter rich in terrestrial and marine organic matter (Munnecke et al., 2001; Weedon, 1986; Smith 1989; Hesselbo et al., 2004; Radley, 2008; Ruhl et al., 2010; Bonis et al., 2010). Rhythmic alternations of limestone and black shale in the Hettangian to Sinemurian Blue Lias Formation of central and southern England have been interpreted as representing 20kyr orbitally-induced, precession cycles, while bundles of distinctive limestone beds result from $\sim 20$-kyr (precession ) to $\sim 40-\mathrm{kyr}$ (obliquity) harmonics (Weedon et al., 1999; Paul et al., 2008; Ruhl et al., 2010). Furthermore, some of the distinctive limestone -shale couplets, such as the 'Thick Rock' seen in the study area, can be recognised over tens of kilometres, suggesting a basin-wide, allogenic forcing mechanism such as high frequency climate control (Weedon, 1986; Smith, 1989; Ruhl et al., 2010). 
In this paper we report exceptionally high levels of Mo together with enhanced levels of $\mathrm{Cu}$ and $\mathrm{U}$ in the Blue Lias Formation and Charmouth Mudstone Formation as revealed by regional geochemical surveys based on the results of systematic soil and stream sediment sampling (http://www.bgs.ac.uk/downloads/start.cfm?id=1633). In order to determine more accurately the origin of the high metal values at the bed/lamina level over this stratigraphical interval, two shallow boreholes were drilled in the Southam area (Figure 1b) in the north-east of the anomaly, and further handspecimen samples were collected from quarries in the area. Interbedded black mudstone and limestone samples from the boreholes and quarries were separately analysed by X-ray fluorescence spectrometry (XRFS) methods to determine the levels of these metals in these two distinctive lithologies. Further quantitative X-ray diffraction (XRD) analysis of the metal-rich mudstones was carried out to find out if there was any variation in the metals in component siliciclastic and bioclastic grains.

The geochemical results of this study are assessed in the context of sedimentation, deposition environment and sea-level change during the Early Jurassic. In addition to the determination of metal enrichment, especially of Mo in the black mudstones, we discuss the potential bio-accessibility of these elements in arable crops and livestock food chains and their potential health effects.

\section{Geological background}

The Lower Jurassic Lias Group (Powell, 1984) of southern and southwest England (Cox et al., 1999) comprises mudstone, limestone and sandstone deposited in a 
shallow, broad epeiric sea that was fully, or partially, connected to the Tethys Ocean (Donovan, 1992). During the Hettangian to Sinemurian stages (199.6 to 189.6 Ma duration; Ogg et al., 2008) the lime mud and organic-rich lime mud of the Blue Lias Formation were deposited to the northwest of the partly emergent London (AngloBrabant) Landmass in epicontinental marine environments that were influenced by eustatic and regional sea-level fluctuations during a warm climate phase (Hallam, 1975; Hallam and Sellwood, 1976; Simms et al., 2004). The Hettangian to Sinemurian was a phase of world-wide sea-level rise (Hallam, 1997, 2001; Hesselbo and Jenkyns, 1998).

The area of the anomaly (Figure 1b) includes the south-western part of the East Midlands Shelf and spans the northeast-trending Vale of Moreton Axis to include the north-eastern part of the Worcester basin (Cox et al., 1999). Here, the Blue Lias Formation (Ambrose, 2001) (Hettangian to early Sinemurian in age) comprises, in upward sequence, the Wilmcote Limestone Member, Saltford Shale Member and Rugby Limestone Member and is overlain by the Charmouth Mudstone Formation (Figure 1c, Ambrose, 2001). The Mo anomaly reported here extends from Dunchurch near Rugby in the north-east to Evesham (and beyond) in the south-west (Figure 1b). This anomaly broadly coincides with the outcrop of the Blue Lias Formation and the lower part of the Charmouth Mudstone Formation, and its distribution is offset by a number of faults that also displace the outcrop of the Lias Group, for instance the NNW-trending Princethorpe Fault which downthrows to the northeast, and a number of similar trending faults between Stratford-upon-Avon and Atherstone-on-Stour (Figure 1b). This suggests that the soil anomaly is related to enhanced metal 
concentrations in the bedrock geology rather than exotic Quaternary superficial deposits or regolith materials.

In the Worcester Basin and southern part of the East Midlands Shelf, the proportion of black or dark grey mudstone to thin bedded limestone varies through the Blue Lias Formation succession (Ambrose, 2001). In the lower part, the Wilmcote Limestone Member is a limestone-dominated unit consisting of thin bedded micritic limestone alternating with thin dark grey and black calcareous mudstone beds; it is present only west of Stratford-on-Avon. The high limestone: mudstone ratio in this unit may indicate a shallower depositional environment and proximity to the shoreline of the London Landmass of the Vale of Moreton Axis, as compared with the coeval succession on the Dorset Coast (Simms et al., 2004; Radley, 2008). The Wilmcote Limestone Member is absent northeast of Stratford-on-Avon and the Saltford Shale member rests disconformably on the Rhaetian White Lias Formation (Penarth Group). The Saltford Shale Member (Hettangian) has only a few limestone interbeds; limestones in the upper part of the member contain abundant bioclasts including bivalves and echinoid fragment, and show evidence of erosive scouring below storm wave base (Radley, 2008). The overlying Hettangian to early Sinemurian Rugby Limestone Member (ca.25 m thick) comprises dark grey laminated organic rich mudstone and pale grey, non-laminated calcareous mudstone rhythmically interbedded with bioturbated, bioclastic limestones (Old et al., 1987; Ambrose, 2001). Individual limestone and black mudstone beds can be traced over several miles. Increase in the relative proportion of bioclastic limestones and an increase in the shelly content indicates an upward shallowing trend from the upper part of the 
Saltford Shale to the Rugby Limestone members. The Rugby Limestone is of Angulata and Bucklandi zone age (Clements, 1975; Old et al., 1987; Ambrose, 2001).

\section{The G-BASE regional geochemical survey project}

The Geochemical Baseline Survey of the Environment (G-BASE) is a longestablished, high-resolution regional geochemical mapping project run by the British Geological Survey, aimed at making a complete geochemical survey for the whole UK landmass, and is described in detail in several publications (Johnson and Breward, 2004; Johnson et al., 2005). When sampling commenced in the late 1960s the work was stimulated by, and oriented towards, mineral exploration, but this high-resolution survey has evolved continuously and now has many environmental applications. The geochemical mapping, originally based on the collection of wet-sieved drainage sediments (sub-150 $\mu \mathrm{m}$ fraction) at a target sampling density of one stream sediment sample per square kilometre, has expanded to include the sampling and analysis of stream waters and soils (sub-2 mm fraction) and now also includes the systematic high-resolution sampling of urban soils (Fordyce et al., 2005). Solid materials are analysed for approximately 50 elements by XRFS, and filtered stream waters $(0.45 \mu \mathrm{m})$ are analysed mainly by Inductively-coupled Plasma Atomic Emission Spectrometry (ICP-AES) and Inductively-coupled Plasma Mass Spectrometry (ICPMS) for up to 35 elements, plus parameters such as $\mathrm{pH}$ and conductivity by other methods. Consequently, with such a high resolution survey, a wide range of elements, and nearly eighty-five percent of the UK land area covered (at least for drainage 
samples), the BGS Geochemistry Database now contains data for some five million individual element determinations.

In addition to presenting results in a series of hard-copy and web-based geochemical atlases (e.g. British Geological Survey, 2000), G-BASE samples and data are utilised in a wide range of applications and reported in peer-reviewed publications. The interpretation of the regional geochemistry is carried out in the context of the geology and other available geoscience and historical information such as mineral occurrences, land use, industrial and other anthropogenic influences. Recent publications have shown how widely these regional geochemical data can be used: to interpret subtle geological changes (Stone et al., 2004; Breward et al., 2011); to demonstrate the relationships between soils, heavy metal pollution and parent material (Breward, 2003, 2007, Johnson et al., 2011 and Rawlins et al., 2003); glaciation studies (Scheib et al., 2011); in bioaccessibility studies (Palumbo-Roe et al., 2005); in archaeology (Chenery et al., 2001); environmental radioactivity (Jones et al., 2009); surface water quality research (Begum et al., 2010); and to better inform legislation such as defining normal levels of contaminants in soils for the UK Part 2A contaminated land Statutory Guidance (Johnson et al., 2012).

In the area of interest (Figures 1a and b), which is mainly a sub-area of the Central and Eastern England regional survey, soil samples were taken on a grid pattern at a sampling density of one sample per two square kilometres. Two soil samples were taken at each site: a topsoil extending to about 5-20 cm depth, and a deep soil at 35$50 \mathrm{~cm}$ depth. Stream sediments and stream waters were taken from natural first and 
second-order streams, and were therefore limited to those areas of suitable surface drainage. An average sampling density of one sample per 1.7 square kilometres was achieved for stream sediments and stream waters over the area of interest.

Bedrock samples are not routinely taken in the G-BASE project, so in order to elucidate the source of the high Mo levels within the stratigraphic sequence, several active and disused cement quarries in the Southam area were visited and sampled in early 2010, and shallow borehole samples were also taken from notably anomalous areas.

\section{Geochemical map creation and interpretation}

Regional geochemical data are best presented as thematically coloured maps, either as interpolated gridded raster images or as proportion symbols centred on the sample locations. These may be produced by a variety of software packages - the gridded images shown here (Figures 2 and 3) were generated using the square-law inversedistance weighting (IDW) gridding module within the ArcGIS 9.3 GIS package, where further layers of geological and geographical information were added. The proportional symbol maps of soils and stream sediments (on Figure 1b) were also produced in ArcGIS 9.3. 


\section{Methods}

\section{Soil and stream sediment sampling}

The methodology for the G-BASE sampling of soils and stream sediments is fully described in Johnson and Breward (2004); Johnson et al., (2005) and British Geological Survey, (2000). Also available is a sampling factsheet, downloadable from the BGS website at http://www.bgs.ac.uk/downloads/start.cfm?id=1254.

\section{Rock sampling}

Bedrock samples were collected from the currently active Long Itchington cement works quarry (Clements, 1975; Old et al., 1987) near Southam, and the disused quarries at Harbury and Stockton (Old et al., 1987) (Fig. 1). The exposed stratigraphy was logged, and samples selected to include the typical limestone-mudstone lithologies as well as the most obvious black 'paper shales' which were suspected to be the most likely source of the high Mo values. Two shallow boreholes were also drilled, using the BGS 'Dando Terrier 2002' shallow drilling rig at Lower Farm and Dadglow Farm on the soil anomaly close by, reaching depths of $5.9 \mathrm{~m}$ and $9.7 \mathrm{~m}$ respectively, and were selectively sampled to provide a further 15 rock samples of varying lithology including limestone, grey calcareous mudstone, and thinly laminated black 'paper shale'. Graphic logs of the quarry sites are shown in Figure 4. 


\section{Lithogeochemical XRFS and mineralogical XRD analyses}

Rock samples collected from the quarry and borehole sites were subjected to XRFS analysis in the BGS laboratories using similar analytical programs to those used for soils and streams sediments in the G-BASE project, in order to minimise analytical variation and thus facilitate comparison between the data sets. Thus pressed powder pellet technology was used for the whole range of elements, rather than the alternative fused bead method, which would give greater accuracy and precision on the major elements (such as $\mathrm{Fe}_{2} \mathrm{O}_{3}$ and $\mathrm{CaO}$ ), but this was not considered essential as the main interest was in the trace element concentrations. A full description of the method, accuracy and precision of the XRFS data generated in the G-BASE programme is given in British Geological Survey (2000). The rock samples were also submitted for loss on ignition (LOI, $450^{\circ} \mathrm{C}$ ) determination to provide an estimate of their organic matter content.

A sub-set of fifteen of the rock samples were also submitted for XRD (X-ray diffraction) mineralogical analysis in the BGS laboratories in order to elucidate the source or host mineralogy for the anomalous metals, especially the high Mo values. The 15 selected rock hand specimen and core samples were received from the BGS Sample Preparation Facility as both jaw-crushed and milled subsamples in order to determine the mineralogy, and in particular the clay mineralogy, of the samples. 


\section{Preparation}

In order to achieve a finer and uniform particle-size for powder XRD analysis, approximately $4.5 \mathrm{~g}$ portions of the ball-milled material were micronised under deionised water for 10 minutes with $10 \%$ (i.e. 0.5 g) corundum (American Elements, $\left.\mathrm{Al}_{2} \mathrm{O}_{3}, \mathrm{AL}-\mathrm{OX}-03-\mathrm{P}\right)$. The addition of an internal standard allows validation of quantification data and also the detection of any amorphous species in the samples. Corundum was selected as its principle XRD peaks are suitably remote from those produced by most of the phases present in the samples and its mass absorption coefficient is similar to the sample matrix.

All corundum-spiked samples were then spray-dried following the method and apparatus described by Hillier (1999). The spray-dried materials were then frontloaded into standard stainless steel sample holders for analysis. Further subsamples of the jaw-crushed material (typically $~ 10$ g) were dispersed in deionised water using a reciprocal shaker combined with ultrasound treatment. Each suspension was then sieved on $63 \mu \mathrm{m}$ and the $<63 \mu \mathrm{m}$ material placed in a measuring cylinder and allowed to stand. In order to prevent flocculation of the clay crystals, $1 \mathrm{ml}$ of $0.1 \mathrm{M}$ 'Calgon' (sodium hexametaphosphate) was added to each suspension. After a time period determined from Stokes' Law, a nominal $<2 \mu \mathrm{m}$ fraction was removed and dried at $55^{\circ} \mathrm{C}$.

Approximately $100 \mathrm{mg}$ of the $<2 \mu \mathrm{m}$ material was then re-suspended in a minimum of deionised water and pipetted onto a ceramic tile in a vacuum apparatus to produce an oriented mount. The mounts were Ca-saturated using $2 \mathrm{ml} 0.1 \mathrm{M} \mathrm{CaCl}_{2} \cdot 6 \mathrm{H}_{2} \mathrm{O}$ solution 
and washed twice to remove excess reagent and allowed to dry at room temperature overnight.

\section{Analysis}

Powder whole-rock XRD analysis was carried out using a PANalytical X'Pert Pro series diffractometer equipped with a cobalt-target tube, X'Celerator detector and operated at $45 \mathrm{kV}$ and $40 \mathrm{~mA}$. The micronised, spray-dried samples were scanned from $4.5-85^{\circ} 2 \theta$ at $2.76^{\circ} 2 \theta /$ minute. Diffraction data were initially analysed using PANalytical X'Pert HighScore Plus version 2.2e software coupled to the latest version of the International Centre for Diffraction Data (ICDD) database.

Less than $2 \mu \mathrm{m}$ oriented mounts were scanned from $2-40^{\circ} 2 \theta$ at $1.02^{\circ} 2 \theta /$ minute after air-drying, ethylene glycol solvation and heating at $550^{\circ} \mathrm{C}$ for 2 hours. Clay mineral species were identified from their characteristic peak positions and their reaction to the diagnostic testing program.

\section{Whole-rock quantification}

Following identification of the mineral species present in the samples, mineral quantification was achieved using the Rietveld refinement technique (e.g. Snyder and Bish, 1989) using PANalytical HighScore Plus software. This method avoids the need to produce synthetic mixtures and involves the least squares fitting of measured to calculated XRD profiles using a crystal structure databank. Errors for the quoted mineral concentrations are typically $\pm 2.5 \%$ for concentrations $>60 \mathrm{wt} \%, \pm 5 \%$ for concentrations between 60 and $30 \mathrm{wt} \%, \pm 10 \%$ for concentrations between 30 and 10 
wt $\%, \pm 20 \%$ for concentrations between 10 and 3 wt $\%$ and $\pm 40 \%$ for concentrations $<3 \mathrm{wt} \%$ (Hillier et al., 2001). Where a phase was detected but its concentration was indicated to be below $0.5 \%$, it is assigned a value of $<0.5 \%$, since the error associated with quantification at such low levels becomes too large.

\section{XRD-profile modelling}

In order to gain further information about the nature of the clay minerals present in the samples, modelling of the XRD profiles was carried out using Newmod-forWindows $^{\mathrm{TM}}$ (Reynolds and Reynolds, 1996) software. Modelling was also used to assess the relative proportions of clay minerals present in the $<2 \mu \mathrm{m}$ fractions by comparison of sample XRD traces with Newmod-for-Windows ${ }^{\mathrm{TM}}$ modelled profiles. The modelling process requires the input of diffractometer scan parameters and a quartz intensity factor (instrumental conditions), and the selection of different sheet compositions (clay minerals are fundamentally built of combinations of twodimensional tetrahedral and octahedral sheets) and chemistries. In addition, an estimate of the crystallite size distribution of the species may be determined by comparing peak profiles of calculated diffraction profiles with experimental data. By modelling the individual clay mineral species in this way, mineral reference intensities were established and used for quantitative standardization following the method outlined in Moore and Reynolds (1997). 


\section{Results}

\section{Regional soil and stream sediment geochemical data.}

The East Midlands regional G-BASE topsoil geochemistry data show a very clear band of elevated Mo values (Figure. 2) over the gently south-east dipping lower Lias Group outcrop extending from just south of the town of Rugby, running southwestwards through Southam to Shipston-on-Stour, then north-north-west to Stratfordupon-Avon as the Lias Group outcrop is offset northwards by faulting, then southwestwards again to Evesham. At Dunsmore, $8 \mathrm{~km}$ south-west of Rugby, the anomaly is seemingly terminated by a thick cross-cutting Quaternary gravel bed, the Dunsmore Gravel, and faulting, but does not reappear over the exposed Lias outcrop to the north. The Mo anomaly extends beyond Evesham, as soils and stream sediments collected from the Wales and West Midlands region (British Geological Survey, 2000) show enhanced Mo levels over the Lias Group outcrop to the west and north, especially over the Rugby Limestone Member outcrop to the east of Worcester. In addition, recent data obtained by BGS re-analysis of soils from the NSI sample archive (Rawlins et al. 2012, McGrath and Loveland, 1992), albeit at a much lower sampling density, suggest that high Mo levels in soils over the lower Lias Group outcrop also extend into South Wales, Gloucestershire and Somerset, though it is not clear whether the same stratigraphic horizon is implied.

In the Midlands section of the anomaly examined here, other elements showing a similar pattern of enrichment include $\mathrm{Cu}$ and $\mathrm{U}$, though these anomalies are not so 
prominent as for Mo. Unusually for a suggested black shale-derived anomaly, and in contrast to others in the UK such as in the Bowland Shale of Lancashire and the Widmerpool Formation of Derbyshire (both of Carboniferous age) which show strong soil vanadium (V) enrichments, up to three times the mean regional background (British Geological Survey, 2006 and http://www.bgs.ac.uk/gbase/geochemicalMaps.

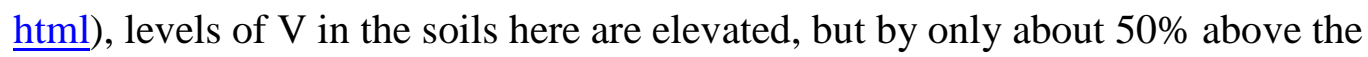
regional background. Element enrichments in comparison to the regional mean and median Mo, $\mathrm{Cu} \mathrm{V}$ and $\mathrm{U}$ values can be seen in Table 1. Molybdenum values reach maxima of $35.8 \mathrm{mg} / \mathrm{kg}$ in the topsoil and $50.5 \mathrm{mg} / \mathrm{kg}$ in the deeper soil samples.

The G-BASE stream sediment data for the East Midlands region also shows a significant spatial Mo anomaly (Figure 3), closely following that shown by the soils and reach a maximum value of $35.4 \mathrm{mg} / \mathrm{kg}$ Mo near Southam. G-BASE stream waters over the anomaly show slight enrichments in both Mo and $U$, but the low levels present are very close to the practical lower limit of detection and are not considered sufficiently reliable for interpretation.

Note that although there are significant increases in the mean and median values for Mo and $\mathrm{Cu}$ over the anomaly compared with the regional values, the high maximum Mo values of the anomaly are indicative of the highly skewed data distribution and this also suggests a high degree of local variation within the outcrop. This is consistent with the likelihood of the Mo-bearing beds being thin black shale units within the thicker Lias Group sequence. 
In the topsoil data, the strongest correlation of $\mathrm{Mo}$ is with $\mathrm{Tl}$, and although other correlations such as with $\mathrm{Cu}, \mathrm{Ni}$ and $\mathrm{V}$ are strong, the scatter plots (Figure 5, $a-h$ ) reveal an increased scatter and greater reliance on the maximum values for the positive trend lines. The deeper soil data (not illustrated) shows very similar plots. The correlations of Mo with the strongly chalcophile elements Tl, Se and Ni suggest that a strong sulphide association is retained; that of Mo with the more organophile elements V, U and Cu suggest a stronger link with organic substrates. The breakdown of the Mo-Fe correlation shown in the rock data, and there attributed to pyrite, shows that any Mo released by pyrite breakdown is certainly not being sorbed by secondary iron oxide phases and is probably being bound instead by soil organic matter or clay minerals.

In the stream sediments, representing the most weathered and therefore most chemically-modified of the sample media, the correlations are weaker still, but many remain statistically significant at the $99 \%$ confidence level. Examination of the scatter plots (Figure 6, $a-h$ ) reveals that the 'resistate' monazite Ce-La correlation remains strong, but that many of the other correlations are now more based on a small number of 'outliers', even single points, in the dataset rather than on a broader spread of values. Consequently, some of the supposed strong correlations are clearly fragile, in that removing just a few high value pairs would destroy the observed correlation. However, the high value pairs are clearly illustrating an important feature - it is unlikely that these are simply statistical anomalies, and a higher density of sampling would almost certainly reveal more of these anomalous pairs. There is again no evidence of sorption of Mo by secondary iron oxides in the stream sediments. 


\section{Rock data}

Thirty-four rock samples taken from quarries and boreholes and comprising examples of the impure limestones, normal 'grey' mudstones and the black paper-shales, were analysed by XRFS. Basic statistics for selected elements for the full suite, broken down by lithology, are shown in Table 2a-c.

The selected scatter plots in Figures $(7, a-h)$ for the rocks show strong relationships with the range of elements noted above, in addition to a positive but weaker link with Fe (although the Mo-Fe plot shows a clear divergence at higher levels, possibly indicating that there may be two different mineral-based populations present), and more typical Cd-Zn and La-Ce correlations. The strongest correlation is Mo-V, although the actual elevation in $\mathrm{V}$ levels above background concentrations is not great. The association of high Mo values with $\mathrm{Cu}, \mathrm{V}, \mathrm{U}$ and Se is, however, consistent with an organic-sulphidic black shale assemblage, the highest levels being more associated with high sulphur than with high organic content for the rock samples. The Mo vs. loss on ignition @ $450^{\circ} \mathrm{C}$ scatter plot (Figure 8a) shows this especially well. However, mainly due to the poor accuracy and precision of the XRFS-determined 'Total sulphur as $\mathrm{SO}_{3}$ ' at low levels, the relationship between $\mathrm{S}$ and Mo in the rocks as shown by the scatter plot (Figure 8b) is clearly uncertain. It is worthy of note that the Mo-Tl correlation is relatively weak in the rock data compared with the soils, suggesting that this association actually strengthens during the weathering process of soil formation, but is weaker in stream sediments possibly due to mobilisation and 
removal in oxygen-rich stream waters of $\mathrm{Mo}$ as soluble $\mathrm{HMoO}_{4}{ }^{-}$anions, whereas $\mathrm{Tl}$ is more likely to be retained in less mobile phases (Brookins, 1988).

\section{Cluster analysis}

Associations between elements in geochemical data sets may also be usefully examined by means of multivariate statistics such as principal component analysis and cluster analysis. Examples of the latter from rocks, soils and stream sediments are given here as dendrograms (Figs. 9-11). For the rock data (Fig. 9), Mo shows almost $90 \%$ similarity with $\mathrm{V}$, and is in a well-defined group of organophile-chalcophile elements viz. V, Ni, $\mathrm{Cu}$, Se and $\mathrm{U}$ (plus $\mathrm{Fe}_{2} \mathrm{O}_{3}$, possibly implying a significant pyritic component), with $\mathrm{Tl}$, Co and As being near associates. Other obvious groupings within the rock data are $\mathrm{Ba}$ with $\mathrm{SO}_{3}$ (suggesting a minor barite component), and $\mathrm{Y}$ Nd-La-Ce- $\mathrm{P}_{2} \mathrm{O}_{5}$ (monazite), whereas $\mathrm{Sr}$ is surprisingly not closely associated with $\mathrm{CaO}$, a curiosity given their usual strong geochemical association in carbonates.

In the soil data (Fig. 10), Mo is most closely linked with $\mathrm{Tl}$ (88\% similarity) with strong links remaining with Se and $\mathrm{S}$, but the association with $\mathrm{Cu}, \mathrm{Ni}$ and $\mathrm{V}$ has been weakened, whereas $\mathrm{Ni}$ and $\mathrm{V}$ are still mutually closely associated. These are also linked to elements normally of resistate character such as $\mathrm{Y}$ and $\mathrm{Nd}$; and others of more clay mineral, even felspathic character such as Ga and Rb. Resistate groupings (Nb-Th, Ce-La, Hf-Zr) are strong at $>90 \%$ similarity, but $\mathrm{Al}$ is more closely associated with $\mathrm{Mg}$ and $\mathrm{Fe}$ than with $\mathrm{Ga}$. Calcium and $\mathrm{Sr}$ remain only weakly associated. 
For the stream sediments (Fig. 11), Mo-Tl remains the strongest association (at 75\% similarity, but see the comment on the scatter plots and correlation above). Calcium and $\mathrm{Sr}$ have become more strongly associated, $\mathrm{Al}$ and $\mathrm{Ga}$ are the clearly-linked pair in clay minerals, $\mathrm{Nb}$ and $\mathrm{Ti}, \mathrm{Cr}-\mathrm{V}$ and $\mathrm{Ce}-\mathrm{La}$ retain close 'resistate' character pairs, whereas $\mathrm{Cu}, \mathrm{Sn}, \mathrm{P}, \mathrm{Pb}$ and $\mathrm{Zn}$ have become a clear grouping, probably more influenced by anthropogenic activity than geogenic sources.

\section{Rock geochemical data - further discussion}

The data for a smaller set of elements from the rock samples are shown as box plots in Figure 12. The data show very interesting results. Of particular note are the extremely high Mo values present in the black paper-shale samples, reaching a maximum of 310 $\mathrm{mg} / \mathrm{kg}$, and there are significant enrichments in $\mathrm{Tl}$ and Se relative to their typical mudstone abundances (1 and $0.3 \mathrm{mg} / \mathrm{kg}$ respectively: Reimann and De Caritat, 1998) although most of the common trace elements show unremarkable concentrations. Iron contents are fairly typical of mudstones, with a median value of around $6.5 \%$, but both the 'grey' and 'black' shales show relatively high $\mathrm{CaO}$ contents. Sulphur data (reported as $\% \mathrm{SO}_{3}-$ though this does not necessarily mean that this is present as sulphate) is not particularly precise by XRFS, but show high values are present in many samples. Given the high sulphur content, it is perhaps surprising that the arsenic (As) content is not higher.

The principal correlations of Mo with other elements in rocks, soils and stream sediments are shown in Table 3. Even recognizing that correlations are not always 
causative, these can nevertheless yield important information, especially when examined in association with scatter plots and other statistical analyses.

\section{Mineralogical analysis}

The quantitative results of whole-rock XRD analyses of the samples are summarised in Table 4. The whole-rock XRD analysis indicates that the samples are composed of variable proportions of silicates, carbonates, sulphides, sulphates, oxides, phyllosilicates and clay minerals. Most of the samples are predominantly composed of 'mica' (undifferentiated mica species possibly including muscovite, biotite, illite and illite/smectite, 35 to $54 \%$, mean $42 \%$ ), calcite (6 to 30\%, mean 19\%), quartz (12 to $19 \%$, mean $15 \%$ ), kaolinite (5 to $12 \%$, mean $7 \%$ ) and dolomite (4 to $11 \%$, mean $7 \%$ ) with smaller, variable quantities of gypsum, pyrite, feldspar, chlorite, anatase and goethite.

The generalised mineralogy of the samples is illustrated in Figure 13. These show broad similarities to the mineralogical analyses of the Lias Group sedimentary rocks presented by Kemp et al. (2005).

The results of $<2 \mu$ m clay mineral analyses for the samples are summarised in Table 5. Example, annotated XRD traces are shown in Figure 14. XRD analysis also indicates the variable presence of quartz, calcite, dolomite and goethite in the $<2 \mu \mathrm{m}$ fractions. Typically these non-clay minerals form only minor/trace components of the $<2 \mu \mathrm{m}$ fractions. However, the $<2 \mu \mathrm{m}$ fractions of some samples (e.g. 12697-0009, 
0013, 0016, 0019, 0025 and 0028) contain a high proportion of calcite. Such high proportions of non-clay minerals in the $<2 \mu \mathrm{m}$ fractions mean that the proportions of clay minerals are lower resulting in lower XRD peak intensities which in turn leads to more difficult speciation and quantification.

The clay mineral assemblages of all the samples are approximately similar and composed of I/S (mean $\sim 50 \%$ ), illite (mean 24\%), kaolinite (mean $~ 21 \%$ ) and trace amounts of chlorite (mean $\sim 5 \%$ ). This assemblage has similar characteristics to that indicated by Kemp et al. (2005) for a sample of Lias Group mudstone from nearby Harbury. 


\section{Discussion}

\section{General}

The combination of regional soil and stream sediment geochemistry, backed up by whole-rock geochemistry and XRD mineralogical analysis, provides a synergistic combination of datasets which together are a powerful tool for the development of our understanding of natural environmental phenomena. Certainly the geochemical and XRD mineralogy datasets are complementary, and confirm the likely association of the very high Mo values with very fine-grained pyrite (and possibly other sulphides) and, to a lesser extent, with organic matter. On progressive aerobic weathering, this pyrite is likely to break down rapidly, releasing Mo which may then bind to organic matter or be mobilised as $\mathrm{MoO}_{4}{ }^{2-}$ or $\mathrm{HMoO}_{4}{ }^{-}$anions. Anaerobic conditions in soils and sediments might lead to a re-precipitation with sulphides, though in the surface environment of the study area this is probably of limited significance as waterlogged anoxic soils are rare. It is more likely that in the soils, the Mo remains nominally 'fixed', but may be readily mobilised by growing crops, for example, where soil mycorrhiza and bacteria will play an important role. The relatively high calcite contents in the samples, even in the black paper shales, were also confirmed. This will partially offset any generation of acid produced by the pyrite weathering by neutralisation, and one consequence of this is that Mo, which is more mobile in neutral to alkaline soils than under low-pH conditions, is likely to have a higher bioavailability than it would in acid soils. 


\section{Agricultural and environmental impact}

A summary of the environmental chemistry of Mo and its biogeochemical behaviour in soils is given in Alloway (1995) and references therein. Molybdenum is a vitallyimportant trace metal in plant metabolism, especially in nitrate reduction and several other processes. Molybdenum is notably concentrated in legumes (such as clovers, Trifolium spp.), where the symbiotic bacterial nitrogen-fixation process relies on Mobearing enzymes. Soil Mo deficiency may be a serious problem for some crops, such as brassicas. However, high Mo levels in soils are well known to pose significant problems in agriculture, such as molybdenosis, a molybdenum-induced $\mathrm{Cu}$ deficiency syndrome in ruminants such as sheep and cattle (Mills and Davis; in Mertz, 1987), symptoms of which include diarrhoea, weight loss, coat discolouration and ultimately death. This has been observed in the UK (Thomson et al., 1972; Thornton, 1977) and more widely in the world, affecting both wild and domestic ruminants (Chappell and Petersen, 1977; Anke et al., 2007).

Discussion with local farmers during field sampling and obtaining permission for the drilling of the test boreholes around Southam revealed that the presence of high Mo values in the local soils was well known, and was a serious concern for some types of agriculture. For example, independent herbage analyses carried out for local farmers had yielded highly significant levels of Mo in hay and other fodder crops, to such an extent that toxic effects had been noted in some farm animals, and local livestock had to receive regular dietary supplements to prevent induced copper deficiency disease. As the anomaly is widespread, these problems must potentially also be present over a 
wide area, and even where crops or existing livestock may not be under threat, changes in farm practice, crops or livestock may show cause future problems.

\section{Palaeogeography and sedimentation}

The anomalously high concentration of molybdenum and associated organophile metal elements hosted in the black shale beds in the study area, compared to relatively low concentrations in these elements in coeval rocks to the north-east, has implications for the palaeo-oceanography of the Early Jurassic epeiric shelf sea, a branch of Neo-Tethys (Cope et al., 1992). There has been much debate concerning the origin and distribution in space and time of Lower Jurassic euxinic black shales and their metal content. For instance, in the stratigraphically higher Early Toarcian oceanic/regional anoxic event (Jenkyns, 1988, Cohen et al., 2004; McArthur et al., 2008; Pearce et al., 2008; Caruthers et al., 2013) of the Cleveland Basin (Powell, 2010), it is uncertain whether the causal mechanism for variation in Mo/TOC and associated metals in black shales is due to local/regional or global anoxia on the seafloor from the semicelatum through exaratum Subzones (Jet Rock) estimated at about 930 kyr duration (McArthur et al., 2000; Cohen et al., 2004). One hypothesis (McArthur et al., 2008; Wignall et al., 2005) favours regional sea-floor anoxia in restricted silled basins (Küspert, 1982) that developed below a pycnocline of lowsalinity, fresh water resulting from enhanced fluvial run-off from the hinterland. Periodic sea-floor anoxia allowed drawdown of Mo in the euxinic sediments. These events were interspersed with a rare to more frequent oxygenation events during the exaratum Subzone to falciferum Zone interval (about 1.24 Ma duration). They 
proposed a lipped sill linked to the Neo-Tethys Ocean so that the sill restricted full oceanic overturn in the shallow epeiric sea except during oxygenation events during periods of higher sea-level. An alternative hypothesis (Jenkyns, 1988; Jenkyns and Clayton, 1997; Cohen et al., 2004; Pearce et al., 2008) favours a global ocean-wide anoxia event over this time interval possibly linked increase in atmospheric carbon dioxide as a result of the release methane hydrates.

The sub-basin restriction and overturn model proposed by McArthur et al. (2008) is a possible mechanism for the regional, patchy concentration of molybdenum in black shales seen in the study area, although there are differences in the lithologies of the Hettangian Blue Lias/Charmouth Mudstone sediments, which have a greater proportion of limestone interbeds, compared to the shale-dominated Toarcian Jet Rock. The model of a lipped basin or a topographically-depressed seafloor where enhanced euxinic bottom conditions are present at the sediment-water interface, such as the anomaly study area, would result in preferential drawdown of Mo in the organic-rich sediments. Overturn and oxygenation of the water column would allow calcareous nanofossils and benthic calcareous organisms to thrive during these periods, resulting in thin beds of bioclastic lime mud to be deposited on the oxygenated sea-floor. However, the lipped basin model does not account for the regular alternation of black shales (anoxic), shelly (wakestone) and micritic limestone beds (oxic) in the Blue Lias and lower Charmouth Mudstone formations seen in the study area (Figure 4), which suggest cyclic changes in seawater chemistry that are reflected in the redox conditions at the sediment/water interface. Hettangian to Sinnemurian limestone-black shale cycles in co-eval sections at St. Audrie's Bay, 
Somerset (Ruhl et al., 2010; Bonis et al., 2010) have been interpreted as the result of precession-scale variations ( 20-kyr) in solar insolation and a concomitant increase in monsoonal activity in low latitudes (Kent and Tauxe, 2005). Black shale beds are interpreted as forming during periods of increased run-off, possibly related to enhanced monsoonal phases (Weedon, 1986; Smith, 1989; Paul et al., 2008; Ruhl et al., 2010; Bonis et al., 2010). Similar limestone-shale cycles described form the Lower Jurassic Redcar Mudstone Formation (Cleveland Basin) have also been interpreted as a result of orbitally induced cyclicity (Van Buchem et al., 1994), although in the Cleveland Basin the siliciclastic beds are less rich in organic material (Powell, 1980; 2010). Increased terrestrial run-off into the basin during enhanced monsoonal phases incorporated abundant terrestrial organic matter (and fine-grained siliciclastics) in a stratified water column (Ruhl et al., 2010; Bonis et al., 2010). Anoxic conditions on the sea-floor were conducive to high Mo drawdown. Slight variations in the palaeotopography of the sea-floor (downwarp), and therefore the depth of the oxic/euxinic interface of the bottom sediments during deposition of the shale beds in the Blue Lias/Charmouth Mudstone cycles, would explain the patchy, but significant, regional variation in Mo and associated organophile metals in the English Midlands as demonstrated in this study (Figure 2). 


\section{Conclusions}

The anomalously high Mo values observed in the soils and stream sediments of the area are due to strong natural enrichments within a black paper-shale sub-facies of the Lower Jurassic bedrock.

For geoscientists, it is important to note that the presence of this anomaly could not have been directly deduced solely from the mapped bedrock geology or geophysical wireline logs, as the extent of the Mo-rich source rocks, and their Mo content was unclear, seemingly even to the cement manufacturers active in the area for whom this is a significant issue. The necessity for proper high-resolution geochemical surveys in identifying and accurately delineating such anomalies, is clearly shown.

The high concentrations of Mo observed in the soils and stream sediments over the anomalous area are certainly exceptional, and are known to have an impact on the local agriculture, with supplementation to treat induced $\mathrm{Cu}$ deficiency in livestock being applied, certainly in the Southam area. The identification of this anomaly and its extent is therefore far more than just a geochemical curiosity, as it has direct relevance to agri-environmental health and productivity issues. It is possible that some previously unidentified agricultural problems could be explained by the presence of these geochemical anomalies.

Defining the potential agricultural and environmental impacts of this anomaly are beyond the scope of this paper, but there is clearly potential for further work in this 
area, with collaborative studies involving geochemists, farmers, veterinary scientists and other agencies likely to yield both quality science and practical applied solutions to farming, land-use and environmental problems.

Rhythmic limestone-Mo-rich black shale beds are interpreted as primary depositional signatures rather than a result of diagenesis and partition of an original mixed limemud. These alternations are interpreted as resulting from orbital precession cycles ( 20-kyr) that resulted in increased terrestrial run-off during phases of increased monsoonal activity, and subsequent incorporation of terrestrial organic matter in the stratified basin. The establishment of euxinic conditions on the sea-floor below a lowsalinity pycnocline resulted in sulphidic Mo enrichment in the muds; periodic overturn of the sea-water column allowed oxygenation of the water column and the sediment-water interface resulting in deposition of bioclastic lime mud. Slight downwarping of the palaeotopography of the Rugby to Evesham area may account for increased local anoxia and higher drawdown of Mo at the sediment-water interface. 


\section{Acknowledgments}

Geology \& geochemistry data, BGS (C) NERC. Contains Ordnance Survey data (C) Crown Copyright and database rights 2012. [Licence Number 100021290].

Thanks are due to the several farmers who allowed access to their land for the borehole sampling (and to the BGS shallow coring team), to Rugby Cement plc for access to the cementstone quarries around Southam and to the Analytical Geochemistry laboratories at BGS Keyworth for the geochemical analyses.

We thank Professor David Wray and an anonymous reviewer for their helpful comments and suggestions.

This paper is published with the permission of the Executive Director, British Geological Survey (NERC). 


\section{References}

Alloway, B.J. (Ed.) Heavy Metals in Soils. 2nd Edition, 1995. Blackie, London.

Ambrose, K. 2001. The Lithostratigraphy of the Blue Lias Formation (Late RhaetianEarly Sinemurian) in the southern part of the English Midlands. Proceedings of the Geologists Association 112, 97-110.

Anke, M., Seifert, M., Holzinger, S., Muller, R. and Schafer, U. 2007. The biological and toxicological importance of molybdenum in the environment and in the nutrition of plants, animals and man. Part 2: Molybdenum in animals and man. Acta Biologica Hungarica, 58(3), 325-333.

Arzani, N. 2004. Diagenetic evolution of mudstones: black shales to laminated limestones, an example from the Lower Jurassic of SW Britain. Journal of Sciences, Islamic Republic of Iran, 15(3), 257-267.

Begum, S., McClean, C.J., Cresser, M.S. and Breward, N. 2010. Can sediment data be used to predict alkalinity and base cation chemistry of surface waters? Science of the Total Environment, 409(2), 404-411.

Bessa, J.L. and Hesselbo, S.P. 1997. Gamma-ray character and correlation of the Lower Lias, SW Britain. Proceedings of the Geologists’ Association, 108, 113-129. 
Bonis, N.R., Ruhl, M. and Kürschner, W.M. 2010. Milankovitch-scale palynological turnover across the Triassic-Jurassic transition at St Audrie's Bay, SW UK. Journal of the Geological Society, London, 167, 877-888.

Bottrell, S. and Raiswell, R. 1989. Primary versus diagenetic origin of Blue Lias rhythms (Dorset, UK): evidence from sulphur geochemistry. Terra Nova, 1, 451-456.

Breward, N. 2003. Heavy-metal contaminated soils associated with drained fenland in Lancashire, UK, revealed by BGS Soil Geochemical survey. Applied Geochemistry, 18, 1663-1670.

Breward, N. 2007. Arsenic and presumed resistate trace element geochemistry of the Lincolnshire (UK) sedimentary ironstones, revealed by a regional geochemical survey using soil, water and stream sediment sampling. Applied Geochemistry, 22, 19701993.

Breward, N., Stone, P., Flight, D.M.A. and Anderson, T.B. 2011. Regional geochemical comparisons from the Lower Palaeozoic, Southern Uplands-DownLongford terrane in Northern Ireland and Scotland. Scottish Journal of Geology, 47(1), 1-12.

British Geological Survey. 1997. Regional Geochemistry of parts of North West England and North Wales -British Geological Survey, Keyworth, Nottingham UK. 
British Geological Survey. 2000. Regional Geochemistry of Wales and part of westcentral England - Sediments and Soils. British Geological Survey, Keyworth, Nottingham UK.

British Geological Survey. 2006. Regional Geochemistry of the Humber-Trent region: stream sediment, soil and stream water. British Geological Survey, Keyworth, Nottingham UK.

Brookins, D.G., 1988. Eh-pH Diagrams for Geochemistry. Springer-Verlag. New York.

Caruthers, A.H., Smith, P.L. and Gröcke, D.R. 2013. The Pliensbachian-Toarcian (Early Jurassic) extinction, a global multi-phased event. Palaeogeography, Palaeoclimatology, Palaeoecology, 386, 104-118.

Chappell, W.R. and Petersen, K. Kellog. (Eds) 1977 Molybdenum in the Environment, Volume 1. Marcel Dekker, New York

Chenery, S.R.N., Phillips, E.R., and Haggerty, G., 2001. An evaluation of geochemical fingerprinting for establishing the provenance of Scottish Red Ware Pottery. Medieval Ceramics, 25, 45-53

Clements, R.G. (Editor). 1975. Report on the geology of Long Itchington Quarry. 30pp (Leicester: Department of Geology, Leicester University) 
Cohen, A.S., Coe, A.L., Harding, S.M. and Schwark, L. 2004. Osmium isotope evidence for the regulation of atmospheric $\mathrm{CO}_{2}$ by continental weathering. Geology, 32, 157-160.

Cope, J.C.W., Ingham, J.K. and Rawson, P.F. (eds.) 1992. Atlas of Palaeogeography and Lithofacies. Geological Society, London, Memoirs, 13.

Cox, B.M., Sumbler, M.G. and Ivimey-Cook, H.C. 1999. A formational framework for the Lower Jurassic of England and Wales (onshore area). British Geological Survey Research Report RR/99/01.

Donovan, D.T. 1992. Early Hettangian. In: Cope, J.C.W., Ingham, J.K., Rawson, P.F. (Eds.), Atlas of Palaeogeography and Lithofacies. Geological Society, London, Memoir 13, 108-109.

Fordyce, F.M., Brown, S.E., Ander, E.L., Rawlins, B.G., O’Donnell, K.E., Lister, T.R., Breward, N. and Johnson, C.C., 2005. GSUE: Urban geochemical mapping in Great Britain. Geochemistry: Exploration Environment Analysis, 5(4), 325-336. Special Volume on Geochemical Mapping.

Hallam, A. 1960. A sedimentary and faunal study of the Blue Lias of Dorset and Glamorgan. Philosophical Transactions of the Royal Society, London, Series B, 243, $1-44$. 
Hallam, A. 1975. Jurassic Environments. Cambridge University Press, Cambridge.

Hallam, A. 1986. Origin of minor limestone-shale cycles: climatically induced or diagenetic? Geology, 14, 609-612.

Hallam, A. 1997. Estimates of the amount and rate of sea-level change across the Rhaetian-Hettangian and Pliensbachian-Toarcian boundaries (latest Triassic to Early Jurassic). Journal of the Geological Society, London, 154, 773-779.

Hallam, A. 2001. A review of the broad pattern of Jurassic sea-level changes and their possible causes in the light of current knowledge. Palaeogeography, Palaeoclimatology, Palaeoecology, 167, 23-37.

Hallam, A. and Sellwood, B.W. 1976. Middle Mesozoic sedimentation in relation to tectonics in the British area. Journal of Geology, 84, 301-321.

Hesselbo, S.P. and Jenkyns, H.C. 1998. British Lower Jurassic sequence stratigraphy In: De Graciansky, P.C., Hardenbol, J., Jacquin, T., Farley, M.B. and Vail, P.R. (eds.) Mesozoic-Cenozoic Sequence Stratigraphy of European Basins. Special Publication of the Society for Sedimentary Geology (SEPM), 60, 561-581.

Hesselbo, S.P., Robinson, S.A. and Surlyk F. 2004. Sea-level change and facies development across potential Triassic-Jurassic boundary horizons, SW Britain. Journal of the Geological Society, London, 161, 365-379. 
Hillier, S. 1999. Use of an air-brush to spray dry samples for X-ray powder diffraction. Clay Minerals, 34, 127-135.

Hillier, S., Suzuki, K. and Cotter-Howells, J. 2001. Quantitative determination of Cerussite (lead carbonate) by X-ray powder diffraction and inferences for lead speciation and transport in stream sediments from a former lead mining area of Scotland. Applied Geochemistry, 16, 597-608.

Ivimey-Cook, H.C. and Powell, J.H. 1991. Late Triassic and early Jurassic biostratigraphy of the Felixkirk Borehole, North Yorkshire. Proceedings of the Yorkshire Geological Society, 48, 367-374.

Jenkyns, H.C. and Clayton, C.J. 1986. Black shales and carbon isotopes in pelagic sediments from the Tethyan Lower Jurassic. Sedimentology, 33, 87-106.

Jenkyns, H.C. 1988. The Early Toarcian (Jurassic) anoxic event: Stratigraphic, sedimentary and geochemical evidence. American Journal of Science, 288, 101-151.

Jenkyns, H.C. and Clayton, C.J. 1997. Lower Jurassic epicontinental carbonates and mudstones from England and Wales: chemostratigraphic signals and the early Toarcian anoxic event. Sedimentology, 144, 687-706. 
Jenkyns, H.C., Jones, C.E., Gröcke, D.R., Hesselbo, S.P. and Parkinson, D.N. 2002. Chemostratigraphy of the Jurassic System: applications, limitations, and implications for palaeoceanography. Journal of the Geological Society, London, 159, 351-378.

Johnson, C.C. and Breward, N. 2004. G-BASE: Geochemical Baseline Survey of the Environment. British Geological Survey Commissioned Report, CR/04/016N

Johnson, C.C., Breward, N., Ander E.L. and Ault, L. 2005. G-BASE: Baseline geochemical mapping of Great Britain and Northern Ireland Geochemistry: Exploration Environment Analysis, 5(4), 347-357. Special Volume on Geochemical Mapping.

Johnson, C.C., Flight, D.M.A., Ander, E.L., Lister, T.R., Breward, N., Fordyce, F.M. and Nice, S.E. 2008. The collection of drainage samples for environmental analyses from active stream channels. Chapter 4, 59-92. In: Site Characterization, Data Analysis and Case Histories. B. De Vivo, Harvey Belkin and Annamaria Lima (Editors). ISBN: 978-0-444-53159-9. Elsevier Science \& Technology.

Johnson, C.C., Demetriades, A., Locutura, J., and Ottesen, R.T., (editors), 2011. Mapping the Chemical Environment of Urban Areas. (Wiley-Blackwell.). 
Johnson, C.C., Ander, E.L., Cave, M.R., and Palumbo-Roe, B. 2012. Normal background concentrations (NBCs) of contaminants in English soils: Final project report. British Geological Survey/Defra Commissioned Report, CR/12/035. Available from NORA.

Jones, D.G., Appleton, J.D., Breward, N., MacKenzie, A.C., Scheib, C., Beresford, N.A, Barnett, C.L, Wood, M.D. and Copplestone, D. 2009. Assessment of naturally occurring radionuclides around England and Wales: application of the G-BASE dataset to estimate doses to non-human species. Radioprotection, 44(5), 629-634

Kemp, S.J., Merriman, R.J. and Bouch, J.E. 2005. Clay mineral reaction progress The maturity and burial history of Lias Group of England and Wales. Clay Minerals, 40(1), 43-61.

Küspert, W. 1982. Environmental changes during oil shale deposition as deduced from stable isotope ratios. In: Einsele, G., Seilacher, A. (Eds), Cyclic and Event Stratification. Springer, Berlin, pp .482-501.

McArthur, J.M., Donovan, D.T., Thirlwall, M.F., Fouke, B.W. and Mattey, D. 2000. Strontium isotope profile of the Early Toarcian (Jurassic) oceanic anoxic event, the duration of ammonite biozones, and belemnite palaeotemperatures. Earth and Planetary Science Letters, 179, 269-285. 
McArthur, J.M., Algeo, T.J., van Schootbrugge, B., Li, Q. and Howarth, R.J. 2008. Basinal restriction, black shales, Re-Os dating and the Early Toarcian (Jurassic) oceanic anoxic event. Palaeoceanography, 23, PA4217.

McGrath, S.P. and Loveland, P.J. 1992. The Soil Geochemical Atlas of England and Wales. Blackie, Glasgow.

Mertz, W. (Ed.) Trace Elements in Human and Animal Nutrition, Vol. 1. Fifth Edition, 1987. Academic Press, San Diego, California.

Moore, D.M. and Reynolds, R.C. 1997. X-Ray Diffraction and the Identification and Analysis of Clay Minerals, Second Edition. Oxford University Press, New York.

Munnecke A., Westphal H., Elrick, M. and Reijmer, J.J.G. 2001. The mineralogical composition of precursor sediments of calcareous rhythmites: a new approach. International Journal of Earth Sciences, 90, 795-812.

Ogg, J.G., Ogg, G. and Gradstein, F.M. 2008. The Concise Geologic Time Scale. Cambridge University Press, pp 177.

Old, R.A., Sumbler, M.G. and Ambrose, K. 1987. Geology of the country around Warwick. British Geological Survey Memoir, England and Wales, Sheet 184. HMSO, London. 
Palfry, J. and Smith, P.L. 2000. Synchrony between Early Jurassic extinction, oceanic anoxic events, and the Karoo-Ferrar flood basalt volcanism. Geology, 28, 747-750.

Palumbo-Roe, B., Cave, M.R., Klinck, B.A., Wragg, J., Taylor, H., O’Donnell, K.E. and Shaw, R.A. 2005. Bioaccessibility of arsenic in soils developed over Jurassic ironstones in eastern England. Environmental Geochemistry and Health, 27, 121-130.

Paul, C.R.C., Allison, P.A. and Brett, C.E. 2008. The occurrence and preservation of ammonites in the Blue Lias Formation (lower Jurassic) of Devon and Dorset, England and their palaeoecological, sedimentological and diagenetic significance. Palaeogeography, Palaeoclimatology, Palaeoecology, 270, 258-272.

Pearce, C.R., Cohen, A.S., Coe, A.L. and Burton, K.W. 2008. Molybdenum isotope evidence for global ocean anoxia coupled with perturbations to the carbon cycle during the Early Jurassic. Geology, 36, 231-234.

Powell, J.H. 1984. Lithostratigraphical nomenclature of the Lias Group in the Yorkshire Basin. Proceedings of the Yorkshire Geological Society, 45, 51-57.

Powell, J.H. 2010. Jurassic sedimentation in the Cleveland Basin: a review. Proceedings of the Yorkshire Geological Society, 58, 21-72. 
Radley, J.D. 2008. Seafloor erosion and sea-level change: Early Jurassic Blue Lias Formation of central England. Palaeogeography, Palaeoclimatology, Palaeoecology, 270, 287-294.

Raiswell, R. 1988. Chemical model for the origin of minor limestone-shale cycles by anaerobic methane oxidation. Geology, 16, 641-644.

Rawlins, B.G., Webster, R., and Lister, T.R., 2003. The influence of parent material on top-soil geochemistry in eastern England. Earth Surface Processes and Landforms, 28, 1389-1409

Rawlins, B.G., McGrath, S.P., Scheib, A.J., Breward, N., Cave, M.R., Lister, T.R., Ingham, M.N., Gowing, C. and Carter, S. 2012. The Advanced Soil Geochemical Atlas of England and Wales. (Keyworth, Nottingham: British Geological Survey.)

Reimann, C. and De Caritat, P., 1998. Chemical Elements in the Environment. Springer-Verlag, Berlin.

Reynolds, R.C. and Reynolds, R.C. 1996. Description of Newmod-for-Windows ${ }^{\mathrm{TM}}$. The calculation of one-dimensional X-ray diffraction patterns of mixed layered clay minerals. R C Reynolds Jr., 8 Brook Road, Hanover, NH. 
Rhul, M., Deenen, M.H.L, Abels, H.A., Bonis, N.R., Krijgsman W. and Kürschner, W.M. 2010. Astronomical constraints on the duration of the early Jurassic Hettangian stage and recovery rates following the end-Triassic mass extinction (St Audrie's Bay/East Quantoxhead, UK), Earth and Planetary Science Letters, 295 (1-2): 262276.

Scheib, A.J., Lee, J.R., Breward, N. and Riding, J.B. 2011. Reconstructing flow paths of the Middle Pleistocene British Ice Sheet in central-eastern England: the application of regional soil geochemical data. Proceedings of the Geologists' Association, 122, $432-444$.

Simms, M.J., Chidlaw, N., Morton, N., and Page, K.N. 2004. British Lower Jurassic Stratigraphy. Geological Conservation Review Series No.30. Joint Nature Conservation Committee, Peterborough.

Simpson, P.R., Breward, N., Cook, J.M., Flight, D., Hall, G.E.M., Lister, T.R. and Smith, B. 1996. High resolution regional hydrogeochemical baseline mapping of stream waters of Wales, the Welsh Borders and West Midlands region. Special Volume Applied Geochemistry, Kracow conference proceedings. 11(5), 621-632.

Smith D.G. 1989. Stratigraphic correlation of presumed Milankovitch cycles in the Blue Lias (Hettangian to earliest Sinemurian), England. Terra Nova, 1, 457-460. 
Snyder, R.L. and Bish, D.L. 1989. Quantitative analysis. In: Bish, D.L., Post, J.E. (Eds), Modern Powder Diffraction, Reviews in Mineralogy, Volume 20, Mineralogical Society of America, USA, pp. 101-144 (Chapter 5).

Stone, P., Breward, N., Merriman, R.J., and Plant, J.A. 2004. Regional geochemistry of cryptic geology: variations in trace element distribution across the Southern Uplands terrane, Scotland. Applied Earth Science (Trans. Inst. Min. Metall. Section B) March 2004 Vol. 113 B43-B57.

Thomson, I., Thornton, I. and Webb, J.S. 1972. Molybdenum in black shales and incidence of bovine hypocuprosis. Journal of the Science of Food and Agriculture, 23(7), 871-891.

Thornton, I. 1977. Biogeochemical studies on Molybdenum in the United Kingdon. In: Molybdenum in the Environment, Volume 2: The geochemistry, cycling and industrial uses of molybdenum. Chappell, W.R. and Petersen, K. Kellog (Eds.). Marcel Dekker, New York

Van Buchem F.S.P., Melynk, D.H. and McCave, I.N. 1992. Chemical cyclicity and correlation of the Lower Lias Mudstones using gamma ray logs, Yorkshire, UK. Journal of the Geological Society, London, 149, 991-1002. 
Van Buchem, F.S.P., McCave, I.N. and Weedon, G.P. 1994. Orbitally induced smallscale cyclicity in a siliciclastic epicontinental setting (Lower Lias, Yorkshire, UK). Special Publications of the International Association of Sedimentologists, 19, 345366.

Whittaker, A., Holliday, D.W. and Penn, I.E. 1985. Geophysical logs in British stratigraphy. Special Report of the Geological Society of London, 18.

Wignall, P.B., Newton, R.J. and Little, C.T.S. 2005. The timing of palaeoenvironmental change and cause-and-effect relationships during the Early Jurassic mass extinction, Europe. American Journal of Science, 305, 1014-1032.

Weedon, G.P. 1986. Hemipelagic shelf sedimentation and climatic cycles, the basal Jurassic (Blue Lias) of South Britain. Earth and Planetary Science Letters, 76, 321335. 


\section{Figures}

1. a. Location map, Rugby - Evesham area.

b. Geology and geochemistry map illustrating Mo data for soils and stream sediments, Rugby - Evesham area.

c. Simplified Upper Triassic and Lower Jurassic stratigraphy of the study area (not to scale).

2. Interpolated Mo anomaly map for soils, Rugby - Evesham area.

3. Interpolated Mo anomaly map for stream sediments, Rugby - Evesham area.

4. Graphic logs and location of samples for the Rugby Limestone Member (Blue Lias Formation) at Long Itchington and Stockton quarries. Long Itchington modified after Clements (1975) and Old et al., (1987); Stockton modified after Old et al., (1987).

5. Geochemical scatter plots for soil data.

6. Geochemical scatter plots for stream sediment data.

7. Geochemical scatter plots for rock data.

8. a. Scatter plot for Mo vs. loss on ignition (at $450^{\circ} \mathrm{C}$ ) for the 34 rock samples.

b. Scatter plot for Mo vs. Total S (as $\mathrm{SO}_{3}$ ) for the 34 rock samples

9. Cluster-analysis dendrogram for rock data.

10. Cluster-analysis dendrogram for soil data.

11. Cluster-analysis dendrogram for stream sediments.

12. a. Box Plots for selected elements in rocks: Mo, V, Cu. Lst = Limestone, Grey = 'grey' or normal calcareous mudstone, Black = Black laminated shales .

b. Box Plots for selected elements in rocks: $\mathrm{Tl}, \mathrm{U}, \mathrm{SO}_{3} \%$.

13. Summary of the whole-rock mineral assemblages of the samples. 
14. Example $<2$ Hm XRD traces, sample 12697-0032. Lower trace (air-dry), middle trace (glycol-solvated), upper trace (heated $550^{\circ} \mathrm{C} / 2$ hours). Peaks are labelled with corresponding $d(\AA)$ spacing. Vertical axis - intensity (counts), horizontal axis $-{ }^{\circ} 2 \theta$ Co-K $\alpha$. 


\section{Tables}

1. Soil and stream sediment Mo, Cu, V and U compositions. Comparison of East Midland's regional mean and median compositions with those for the anomalous area (All values in $\mathrm{mg} / \mathrm{kg}$ ).

2. a. Descriptive geochemical statistics: limestones: $n=5$,

b. Descriptive geochemical statistics: grey shales: $n=4$,

c. Descriptive geochemical statistics: black shales: $n=24$.

3. Pearson Correlation coefficients for the principal elements associated with Mo over the anomaly.

4. Summary of quantitative whole-rock XRD analyses.

5. Summary of the relative percentage of clay minerals in the $<2 \mu \mathrm{m}$ fractions. 
Table 1. Soil and stream sediment Mo, $\mathrm{Cu}, \mathrm{V}$ and $\mathrm{U}$ compositions. Comparison of East Midland's regional mean and median compositions with those for the anomalous area (All values in $\mathrm{mg} / \mathrm{kg}$ ).

\begin{tabular}{|c|c|c|c|c|c|c|}
\hline & & $\begin{array}{c}\text { Regional } \\
\text { mean }\end{array}$ & $\begin{array}{c}\text { Regional } \\
\text { median }\end{array}$ & $\begin{array}{c}\text { Anomaly* } \\
\text { mean }\end{array}$ & $\begin{array}{c}\text { Anomaly } \\
\text { median }\end{array}$ & $\begin{array}{l}\text { Anomaly } \\
\text { maximum }\end{array}$ \\
\hline Topsoil & $\begin{array}{l}\mathrm{Mo} \\
\mathrm{Cu} \\
\mathrm{V} \\
\mathrm{U}\end{array}$ & $\begin{array}{r}0.87 \\
15.4 \\
74.4 \\
1.6\end{array}$ & $\begin{array}{r}0.70 \\
13.9 \\
68.5 \\
1.5\end{array}$ & $\begin{array}{r}5.5 \\
33.3 \\
115 \\
2.6\end{array}$ & $\begin{array}{r}3.5 \\
32.2 \\
117 \\
2.7\end{array}$ & $\begin{array}{r}35.8 \\
65.8 \\
200 \\
4.4\end{array}$ \\
\hline Profile soil & $\begin{array}{l}\mathrm{Mo} \\
\mathrm{Cu} \\
\mathrm{V} \\
\mathrm{U}\end{array}$ & $\begin{array}{r}1.7 \\
25.5 \\
111 \\
2.5\end{array}$ & $\begin{array}{r}1.2 \\
21.5 \\
98.0 \\
2.4\end{array}$ & $\begin{array}{r}5.4 \\
34.9 \\
140 \\
2.4\end{array}$ & $\begin{array}{r}2.9 \\
33.8 \\
136 \\
2.4\end{array}$ & $\begin{array}{r}50.5 \\
62.3 \\
273 \\
6.0\end{array}$ \\
\hline Stream sediment & $\begin{array}{l}\mathrm{Mo} \\
\mathrm{Cu} \\
\mathrm{V} \\
\mathrm{U}\end{array}$ & $\begin{array}{r}2.1 \\
29.1 \\
109 \\
2.7\end{array}$ & $\begin{array}{r}1.3 \\
24.6 \\
105 \\
2.5\end{array}$ & $\begin{array}{r}4.3 \\
36.3 \\
140 \\
2.5\end{array}$ & $\begin{array}{r}3.7 \\
35.0 \\
142 \\
2.6\end{array}$ & $\begin{array}{c}35.4 \\
71.8 \\
235 \\
5.7\end{array}$ \\
\hline
\end{tabular}

*The 'anomaly' in this context is defined as the area of the Lower Lias outcrop where the soil Mo concentration exceeds the 90th percentile of the regional distribution. 
Table 2a. Descriptive geochemical statistics: limestones: $n=5$

\begin{tabular}{|l|c|c|c|c|c|c|c|c|c|}
\hline Variable & Mean & SE Mean & StDev & Minimum & Q1 & Median & Q3 & Maximum & Skewness \\
\hline $\mathrm{CaO} \%$ & 18.43 & 0.65 & 1.44 & 16.12 & 17.27 & 18.67 & 19.46 & 20.1 & -1.04 \\
\hline $\mathrm{Fe}_{2} \mathrm{O}_{3} \%$ & 4.76 & 0.20 & 0.46 & 4.17 & 4.30 & 4.93 & 5.13 & 5.3 & -0.25 \\
\hline $\mathrm{V}$ & 99.6 & 2.93 & 6.54 & 91.6 & 93.7 & 98.6 & 105.9 & 108.3 & 0.25 \\
\hline $\mathrm{Ni}$ & 45.3 & 2.48 & 5.54 & 39.4 & 41.05 & 42.9 & 50.9 & 53.5 & 0.79 \\
\hline $\mathrm{Cu}$ & 32.0 & 2.44 & 5.45 & 25.5 & 26.95 & 31.9 & 37.1 & 39.5 & 0.31 \\
\hline $\mathrm{Zn}$ & 58.0 & 5.12 & 11.45 & 49.0 & 50.4 & 54.5 & 67.5 & 77.8 & 1.85 \\
\hline $\mathrm{As}$ & 9.94 & 1.96 & 4.39 & 5.9 & 6.5 & 7.9 & 14.4 & 16.5 & 0.97 \\
\hline $\mathrm{Se}$ & 0.80 & 0.08 & 0.19 & 0.5 & 0.65 & 0.8 & 0.95 & 1.0 & -1.15 \\
\hline $\mathrm{Zr}$ & 111.5 & 3.51 & 7.84 & 100.8 & 105.7 & 111.3 & 117.5 & 122.9 & 0.20 \\
\hline $\mathrm{Mo}$ & 5.96 & 1.53 & 3.42 & 2.5 & 3.75 & 5.1 & 8.6 & 11.7 & 1.52 \\
\hline $\mathrm{Tl}$ & 0.64 & 0.10 & 0.23 & 0.3 & 0.4 & 0.8 & 0.8 & 0.8 & -1.02 \\
\hline $\mathrm{Pb}$ & 14.28 & 0.66 & 1.48 & 12.5 & 12.75 & 14.8 & 15.55 & 16.0 & -0.25 \\
\hline $\mathrm{U}$ & 3.54 & 0.43 & 0.96 & 2.3 & 2.60 & 3.6 & 4.45 & 4.6 & -0.26 \\
\hline $\mathrm{Cd}$ & 0.32 & 0.15 & 0.33 & 0.1 & 0.15 & 0.2 & 0.55 & 0.9 & 2.13 \\
\hline $\mathrm{La}$ & 30.8 & 0.58 & 1.30 & 30.0 & 30.0 & 30.00 & 32.0 & 33.0 & 1.71 \\
\hline $\mathrm{Ce}$ & 52.2 & 1.24 & 2.77 & 49.0 & 49.5 & 52.00 & 55.0 & 55.0 & 0.01 \\
\hline $\mathrm{SO} \%$ & 1.68 & 0.07 & 0.15 & 1.50 & 1.55 & 1.70 & 1.80 & 1.9 & 0.55 \\
\hline
\end{tabular}

Table 2b. Descriptive geochemical statistics: Grey shales: n=4

\begin{tabular}{|l|c|c|c|c|c|c|c|c|c|}
\hline Variable & Mean & SE Mean & StDev & Minimum & Q1 & Median & Q3 & Maximum & Skewness \\
\hline $\mathrm{CaO} \%$ & 13.50 & 1.05 & 2.10 & 10.41 & 11.32 & 14.24 & 14.93 & 15.1 & -1.74 \\
\hline $\mathrm{Fe}_{2} \mathrm{O}_{3} \%$ & 5.44 & 0.16 & 0.32 & 5.15 & 5.15 & 5.41 & 5.75 & 5.8 & 0.15 \\
\hline $\mathrm{V}$ & 126.3 & 5.57 & 11.13 & 112.4 & 115.2 & 126.9 & 136.6 & 138.8 & -0.31 \\
\hline $\mathrm{Ni}$ & 50.2 & 2.39 & 4.79 & 45.7 & 46.1 & 49.3 & 55.2 & 56.5 & 0.84 \\
\hline $\mathrm{Cu}$ & 37.9 & 5.38 & 10.8 & 27.4 & 28.4 & 36.4 & 48.9 & 51.3 & 0.56 \\
\hline $\mathrm{Zn}$ & 88.5 & 26.5 & 52.9 & 52.7 & 53.0 & 68.00 & 144.4 & 165.2 & 1.64 \\
\hline $\mathrm{As}$ & 10.53 & 1.88 & 3.76 & 8.0 & 8.15 & 9.00 & 14.43 & 16.1 & 1.86 \\
\hline $\mathrm{Se}$ & 1.20 & 0.14 & 0.29 & 0.9 & 0.92 & 1.20 & 1.47 & 1.5 & 0.00 \\
\hline $\mathrm{Zr}$ & 117.9 & 5.22 & 10.44 & 108.6 & 109.6 & 115.3 & 128.8 & 132.4 & 1.23 \\
\hline $\mathrm{Mo}$ & 10.6 & 3.4 & 6.8 & 4.0 & 5.2 & 9.1 & 17.5 & 20.1 & 1.23 \\
\hline $\mathrm{Tl}$ & 0.72 & 0.25 & 0.50 & 0.1 & 0.22 & 0.75 & 1.20 & 1.3 & -0.26 \\
\hline $\mathrm{Pb}$ & 16.50 & 1.91 & 3.82 & 11.0 & 12.55 & 17.60 & 19.35 & 19.8 & -1.51 \\
\hline $\mathrm{U}$ & 3.5 & 0.38 & 0.76 & 2.4 & 2.7 & 3.9 & 4.0 & 5.0 & -1.81 \\
\hline $\mathrm{Cd}$ & 0.87 & 0.54 & 1.09 & 0.2 & 0.22 & 0.4 & 2.0 & 2.5 & 1.92 \\
\hline $\mathrm{La}$ & 32.75 & 1.93 & 3.86 & 29.0 & 29.25 & 32.5 & 36.5 & 37.0 & 0.17 \\
\hline $\mathrm{Ce}$ & 57.50 & 3.75 & 7.51 & 49.0 & 50.25 & 57.5 & 64.75 & 66.0 & 0.00 \\
\hline $\mathrm{SO} \%$ & 1.75 & 0.15 & 0.31 & 1.50 & 1.52 & 1.65 & 2.07 & 2.2 & 1.60 \\
\hline
\end{tabular}


Table 2c. Descriptive geochemical statistics: Black shales: $n=24$

\begin{tabular}{|l|c|c|c|c|c|c|c|c|c|}
\hline Variable & Mean & SE Mean & StDev & Minimum & Q1 & Median & Q3 & Maximum & Skewness \\
\hline $\mathrm{CaO} \%$ & 11.83 & 0.57 & 2.81 & 6.33 & 9.57 & 11.92 & 13.69 & 18.0 & 0.10 \\
\hline $\mathrm{Fe}_{2} \mathrm{O}_{3} \%$ & 7.00 & 0.17 & 0.86 & 5.65 & 6.46 & 6.73 & 7.68 & 9.1 & 0.86 \\
\hline $\mathrm{V}$ & 182.94 & 6.81 & 33.4 & 112.4 & 162.6 & 185.9 & 198.9 & 260.8 & 0.00 \\
\hline $\mathrm{Ni}$ & 107.0 & 3.80 & 18.64 & 56.5 & 99.0 & 110.9 & 117.5 & 137.6 & -1.10 \\
\hline $\mathrm{Cu}$ & 61.17 & 1.90 & 9.29 & 37.5 & 53.73 & 62.80 & 68.03 & 75.7 & -0.66 \\
\hline $\mathrm{Zn}$ & 176.5 & 16.9 & 82.7 & 82.2 & 122.6 & 157.8 & 192.6 & 465.0 & 2.10 \\
\hline $\mathrm{As}$ & 15.31 & 0.83 & 4.08 & 8.3 & 11.70 & 15.45 & 18.18 & 23.5 & 0.17 \\
\hline $\mathrm{Se}$ & 3.23 & 0.24 & 1.17 & 0.9 & 2.30 & 3.20 & 3.60 & 6.1 & 0.62 \\
\hline $\mathrm{Zr}$ & 109.3 & 1.82 & 8.92 & 97.3 & 100.5 & 109.5 & 113.4 & 131.3 & 0.85 \\
\hline $\mathrm{Mo}$ & 116.9 & 13.4 & 65.8 & 20.1 & 75.5 & 105.7 & 131.1 & 310.5 & 1.39 \\
\hline $\mathrm{Tl}$ & 3.5 & 0.28 & 1.38 & 1.10 & 2.45 & 3.45 & 4.50 & 6.3 & 0.07 \\
\hline $\mathrm{Pb}$ & 27.4 & 1.33 & 6.53 & 19.8 & 24.0 & 25.2 & 28.88 & 47.1 & 2.05 \\
\hline $\mathrm{U}$ & 7.55 & 0.52 & 2.52 & 3.9 & 5.15 & 7.75 & 9.53 & 13.7 & 0.45 \\
\hline $\mathrm{Cd}$ & 1.62 & 0.14 & 0.66 & 0.3 & 1.13 & 1.60 & 1.98 & 3.2 & 0.37 \\
\hline $\mathrm{La}$ & 29.92 & 0.86 & 4.22 & 24.0 & 27.0 & 29.0 & 30.75 & 42.0 & 1.46 \\
\hline $\mathrm{Ce}$ & 54.17 & 1.98 & 9.71 & 43.0 & 48.0 & 52.5 & 58.0 & 84.0 & 1.60 \\
\hline $\mathrm{SO} \%$ & 4.95 & 0.45 & 2.20 & 0.60 & 3.28 & 5.10 & 6.60 & 8.7 & -0.36 \\
\hline
\end{tabular}


Table 3. Pearson Correlation coefficients for the principal elements associated with Mo over the anomaly.

\begin{tabular}{|l|c|c|c|c|c|c|c|}
\hline & Mo-Cu & Mo-Ni & Mo-V & Mo-U & Mo-Tl & Mo-Se & Mo-Fe \\
\hline All Rocks, n= 34 & 0.738 & 0.804 & 0.900 & 0.719 & 0.512 & 0.811 & 0.733 \\
\hline Topsoil, n= 215 & 0.540 & 0.548 & 0.540 & 0.470 & 0.721 & 0.437 & 0.307 \\
\hline Deeper soil, n= 215 & 0.489 & 0.575 & 0.424 & 0.218 & 0.694 & 0.494 & 0.100 \\
\hline Stream Sediment, n= 197 & 0.328 & 0.476 & 0.266 & 0.270 & 0.483 & 0.196 & 0.142 \\
\hline
\end{tabular}

All of these correlations are significant at the 99\% confidence level (soil and stream sediments $\mathrm{R}>0.20$, rocks $\mathrm{R}>0.45$ ) except for Mo-Fe in deep soils and stream sediments. 
Table 4. Summary of quantitative whole-rock XRD analyses

\begin{tabular}{|c|c|c|c|c|c|c|c|c|c|c|c|c|}
\hline \multirow{3}{*}{ LIMS no. } & \multicolumn{12}{|c|}{ mineral (\%) } \\
\hline & \multicolumn{3}{|c|}{ Silicates } & \multicolumn{6}{|c|}{ Carbonates/sulphides/sulphates/oxides } & \multicolumn{3}{|c|}{$\begin{array}{c}\text { Phyllosilicates/clay } \\
\text { minerals }\end{array}$} \\
\hline & 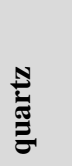 & 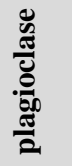 & 竞 & 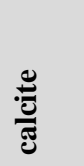 & 을 & 苋 & 恶 & : & 节 & .્ֶ⿹ & 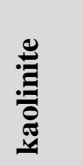 & 을 \\
\hline $12697-0001$ & 17.1 & 1.6 & 2.4 & 22.9 & 4.4 & 1.9 & 0.5 & nd & $<0.5$ & 42.5 & 5.4 & 1.1 \\
\hline $12697-0003$ & 12.9 & 1.6 & 2.8 & 29.7 & 7.6 & 2.5 & nd & nd & $<0.5$ & 36.4 & 5.1 & 1.2 \\
\hline 12697-0005 & 12.2 & 1.7 & 2.0 & 7.5 & 5.5 & 2.6 & 0.5 & nd & $<0.5$ & 54.1 & 12 & 1.6 \\
\hline $12697-0007$ & 12.0 & 1.6 & 2.0 & 12.4 & 6.6 & 2.8 & nd & nd & $<0.5$ & 50.2 & 10.5 & 1.7 \\
\hline 12697-0009 & 14.2 & 0.9 & 1.4 & 18.7 & 6.4 & 4.1 & 7.1 & nd & $<0.5$ & 39.4 & 6.5 & 1.1 \\
\hline $12697-0011$ & 19.3 & 1.4 & 2.1 & 20.8 & nd & 0.9 & nd & 2.1 & $<0.5$ & 45.0 & 6.8 & 1.4 \\
\hline $12697-0013$ & 13.9 & 1.8 & 2.2 & 29.9 & 3.6 & 1.9 & 0.6 & nd & $<0.5$ & 36.6 & 8.1 & 1.2 \\
\hline $12697-0016$ & 14.1 & 1.8 & 2.3 & 27.7 & 9.2 & 1.9 & 0.8 & nd & $<0.5$ & 35.4 & 5.3 & 1.2 \\
\hline $12697-0019$ & 15.2 & 1.8 & 2.6 & 15.8 & 8.8 & 2.8 & 1.2 & nd & $<0.5$ & 43.5 & 7.0 & 1.1 \\
\hline $12697-0022$ & 18.6 & 1.9 & 1.3 & 12.7 & nd & 0.7 & 6.7 & 0.8 & $<0.5$ & 48.4 & 7.1 & 1.5 \\
\hline $12697-0025$ & 17.3 & 2.2 & 1.9 & 24.0 & nd & 1.8 & 4.3 & 1.2 & $<0.5$ & 40.3 & 5.8 & 1.2 \\
\hline $12697-0028$ & 16.8 & 1.7 & 2.6 & 24.6 & 6.6 & 2.0 & nd & nd & $<0.5$ & 38.3 & 6.0 & 1.1 \\
\hline $12697-0030$ & 13.7 & nd & 1.4 & 6.2 & 5.9 & 2.5 & 10.7 & 0.9 & $<0.5$ & 45.0 & 11.5 & 1.8 \\
\hline $12697-0032$ & 16.0 & 0.6 & 0.8 & 10.3 & 4.6 & 8.0 & 6.7 & nd & $<0.5$ & 41.7 & 9.8 & 1.1 \\
\hline $12697-0034$ & 15.9 & 1.5 & 1.9 & 16.0 & 10.9 & 4.1 & 5.3 & nd & $<0.5$ & 38.7 & 4.6 & 1.1 \\
\hline
\end{tabular}

$\underline{\mathrm{KEY}}$

nd: $\quad$ not detected;

'mica’: undifferentiated mica species possibly including muscovite, biotite, illite and illite/smectite 
Table 5. Summary of the relative percentage of clay minerals in the $<2 \mu \mathrm{m}$ fractions

\begin{tabular}{|c|c|c|c|c|c|}
\hline \multirow[b]{2}{*}{ LIMS no. } & \multicolumn{4}{|c|}{ \%clay mineral } & \multirow[b]{2}{*}{ Non-clay minerals } \\
\hline & 兰 & 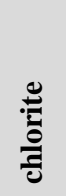 & 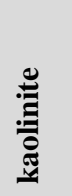 & 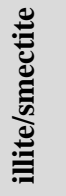 & \\
\hline $12697-0001$ & 28 & 4 & 10 & 58 & quartz, calcite \\
\hline $12697-0003$ & 22 & 7 & 14 & 57 & quartz, calcite \\
\hline $12697-0005$ & 27 & 6 & 34 & 33 & quartz, calcite \\
\hline $12697-0007$ & 20 & 5 & 21 & 54 & quartz, calcite \\
\hline $12697-0009$ & 25 & 6 & 23 & 45 & calcite, quartz \\
\hline $12697-0011$ & 28 & 2 & 25 & 45 & quartz, calcite, goethite \\
\hline $12697-0013$ & 20 & 3 & 22 & 55 & calcite, quartz \\
\hline $12697-0016$ & 21 & 5 & 16 & 58 & calcite, quartz, dolomite \\
\hline $12697-0019$ & 21 & 5 & 20 & 54 & calcite, quartz \\
\hline $12697-0022$ & 23 & 4 & 21 & 52 & quartz, calcite, goethite \\
\hline $12697-0025$ & 27 & 2 & 17 & 54 & calcite, quartz, goethite \\
\hline $12697-0028$ & 25 & 6 & 18 & 50 & calcite, quartz \\
\hline $12697-0030$ & 20 & 3 & 32 & 45 & quartz, calcite, goethite \\
\hline $12697-0032$ & 21 & 5 & 30 & 44 & quartz, calcite \\
\hline $12697-0034$ & 24 & 5 & 18 & 53 & quartz, calcite \\
\hline
\end{tabular}

NOTE

Non-clay mineral names in bold suggest major proportions present

$\mathrm{I} / \mathrm{S}$ is $R 0$ ordered $(60 \% \mathrm{I}, 40 \% \mathrm{~S})$ 


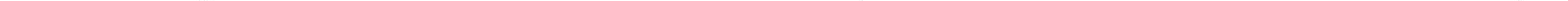




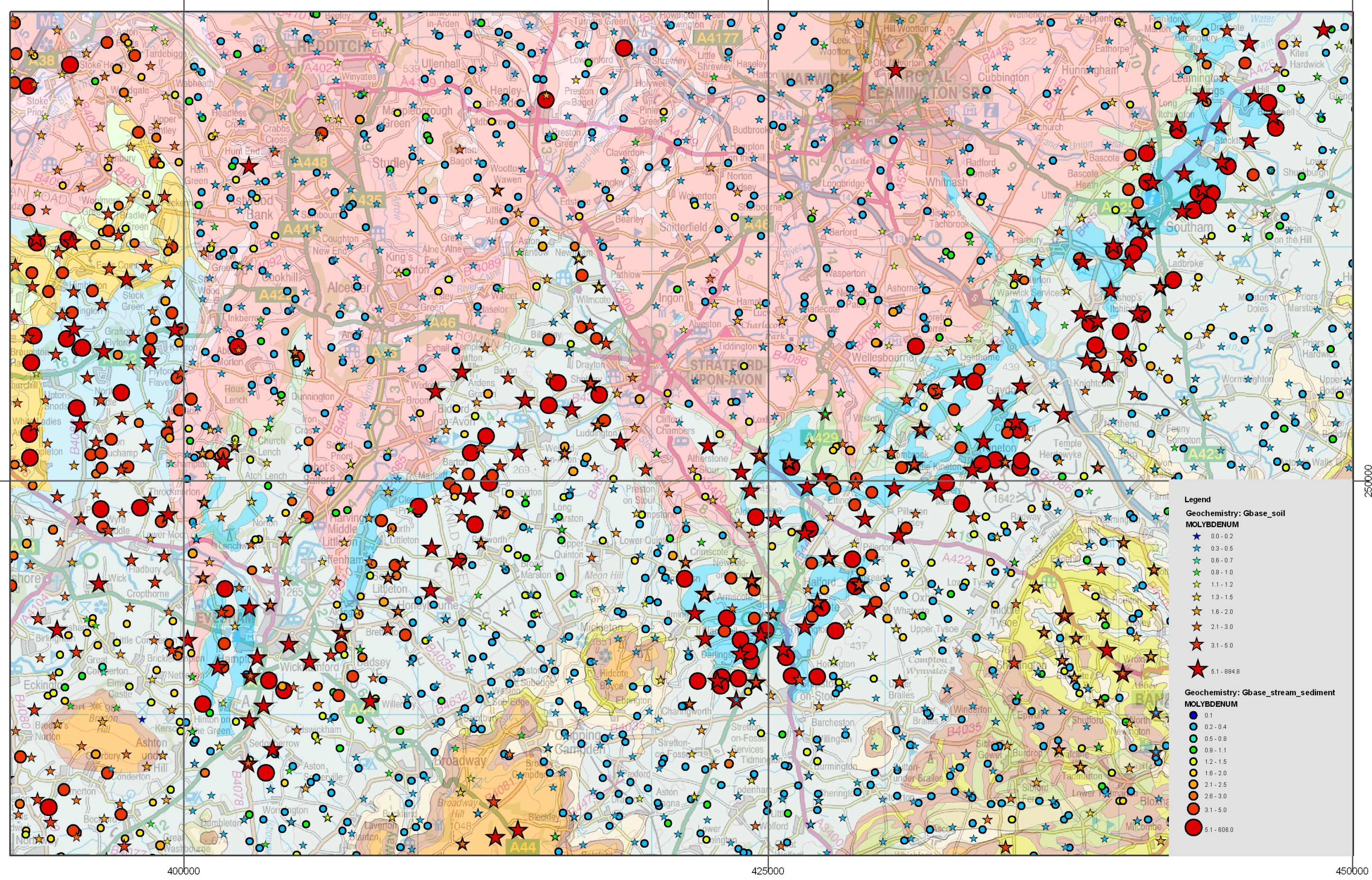


with BGS Rock lexicon codes (not to scale)

\section{EVESHAM-}

WORCESTER BASIN

RUGBY

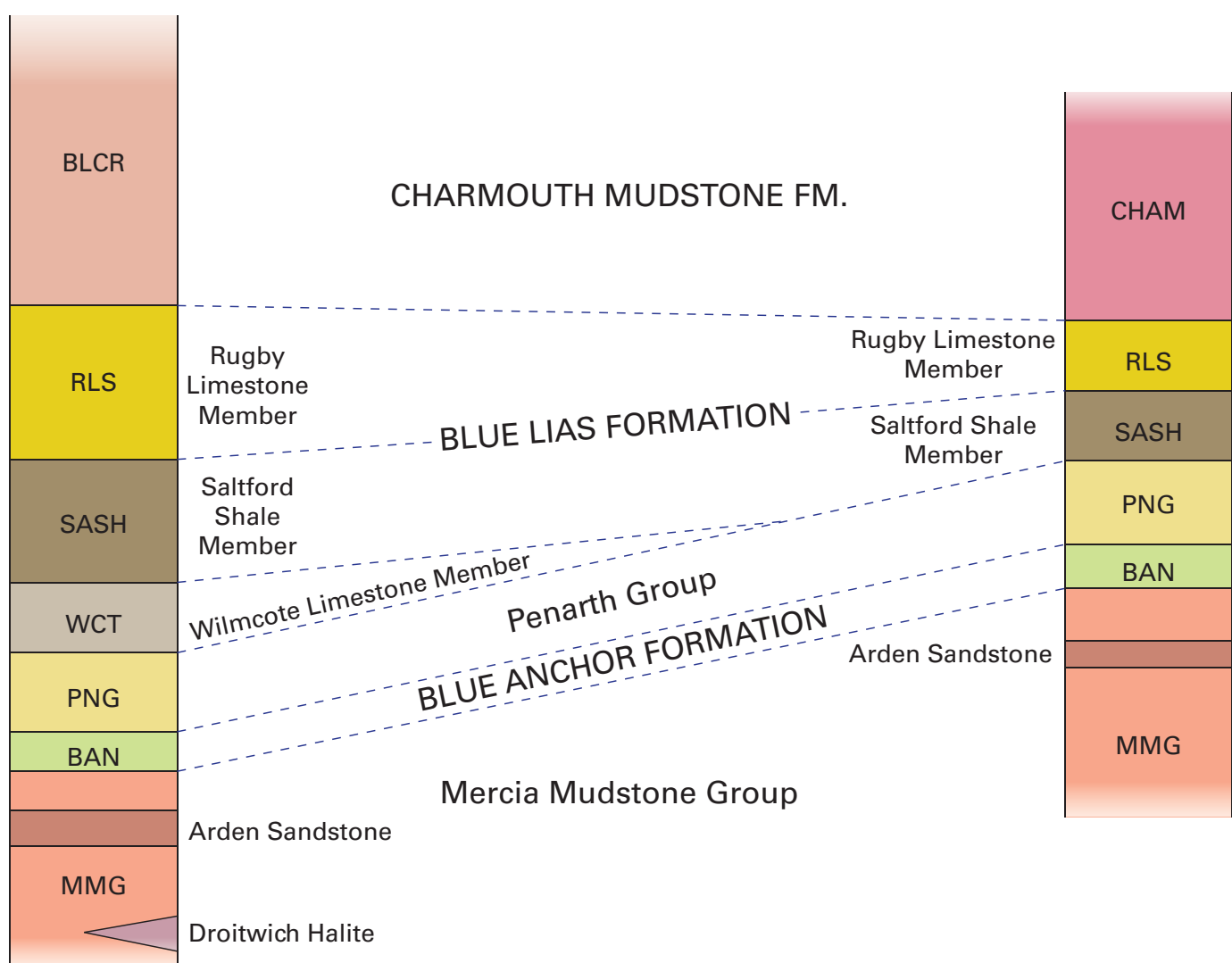




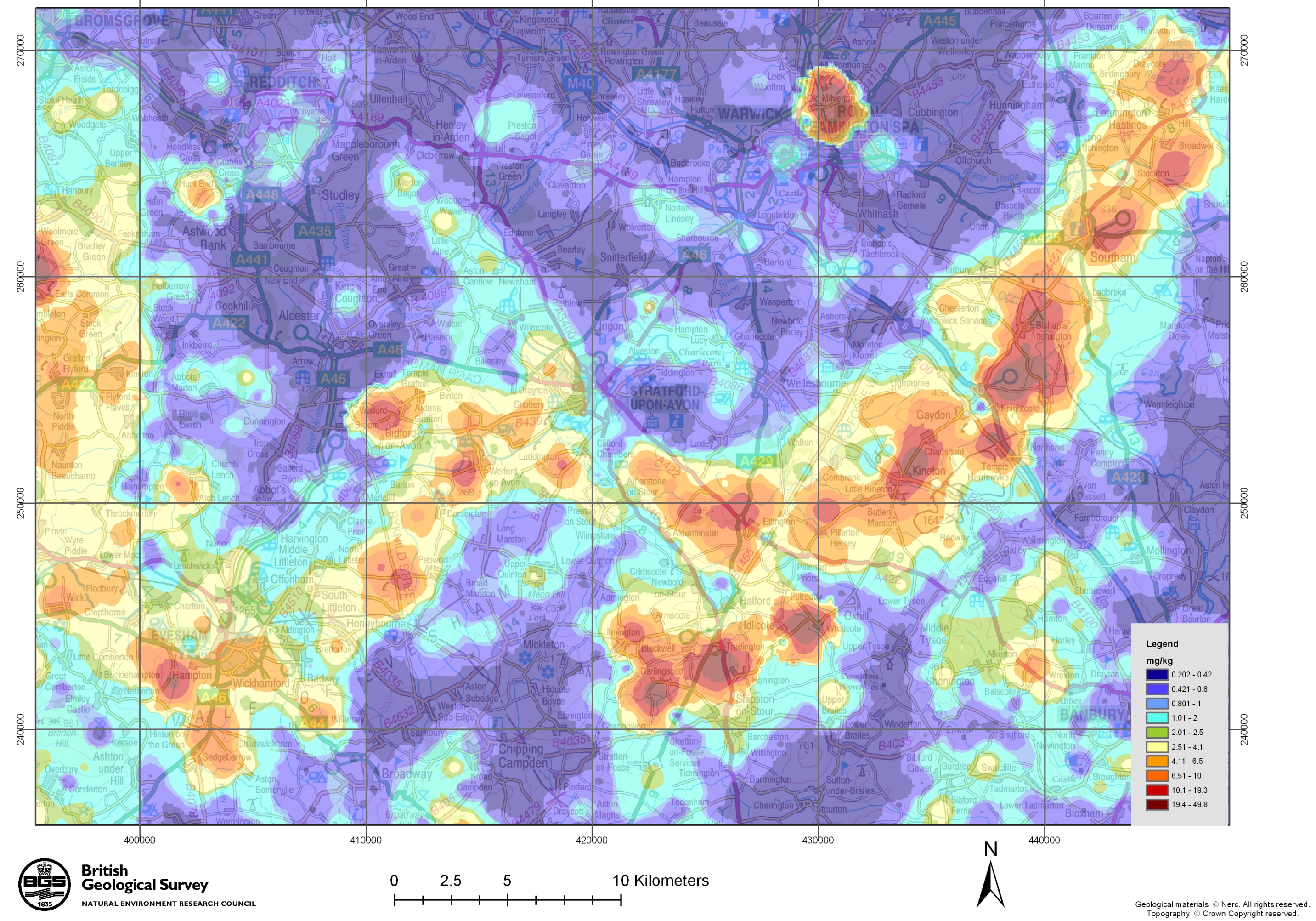




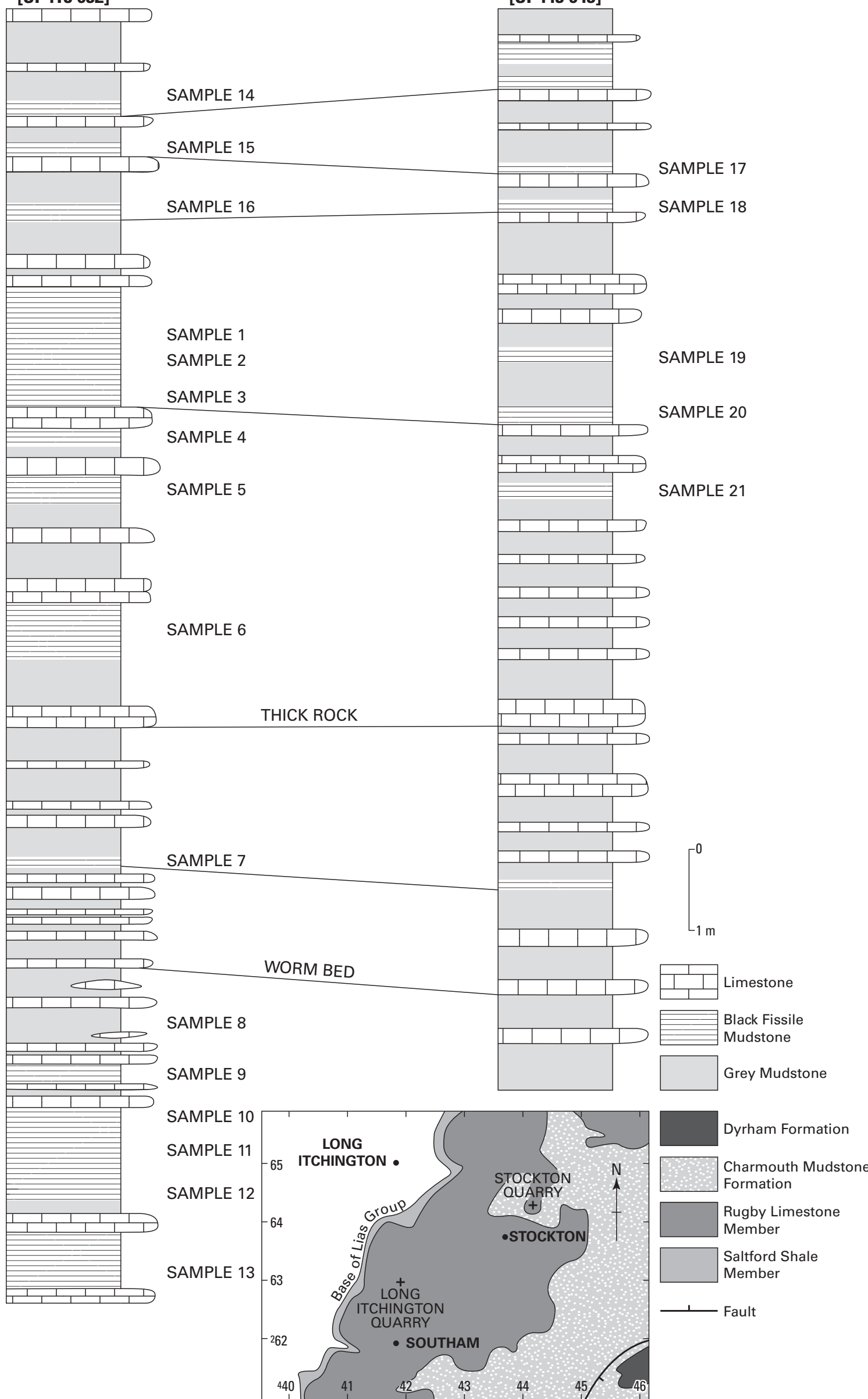




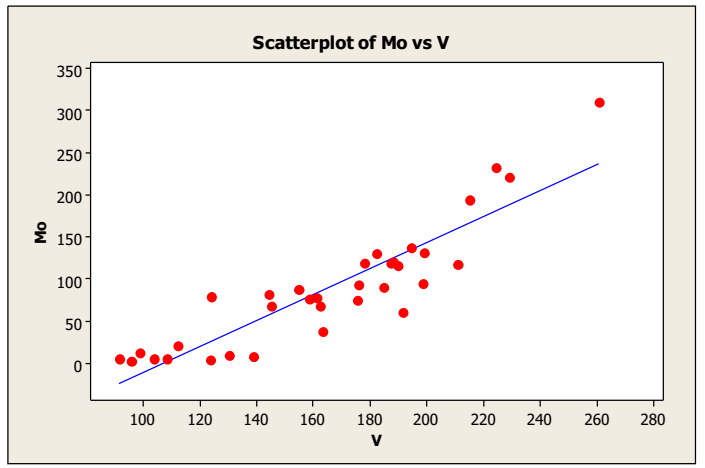

e
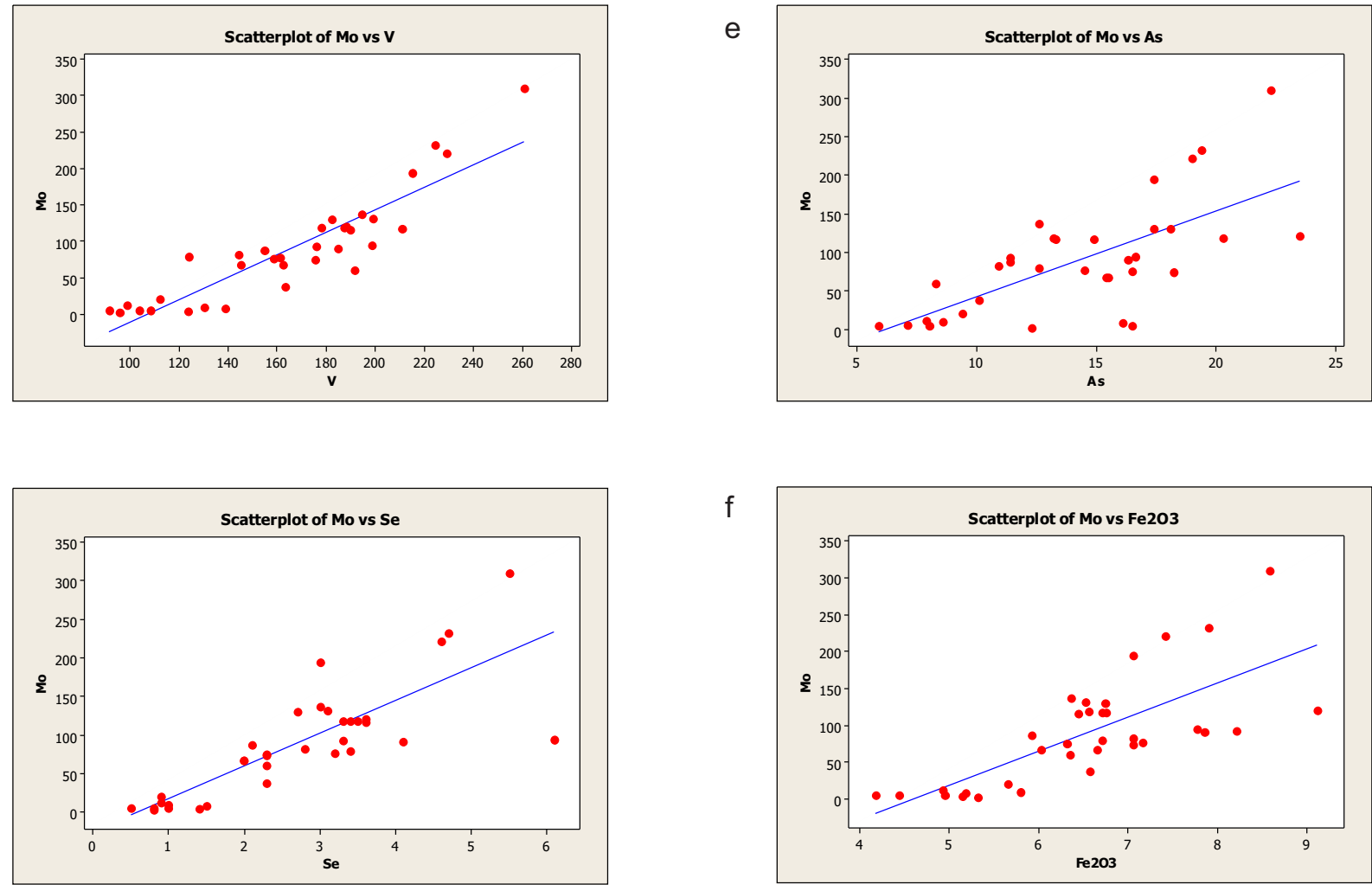

f

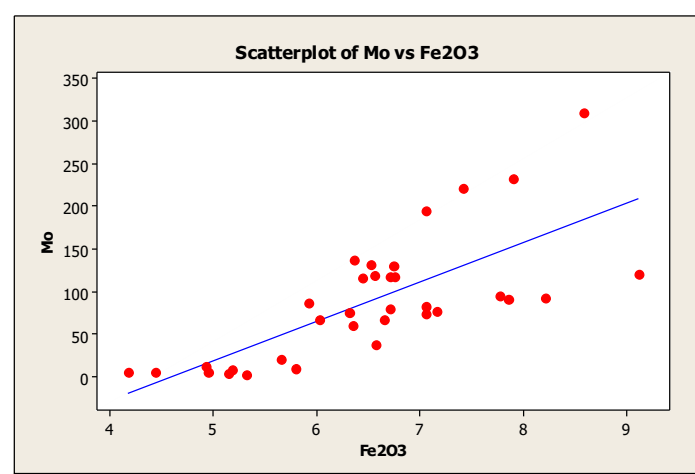

g
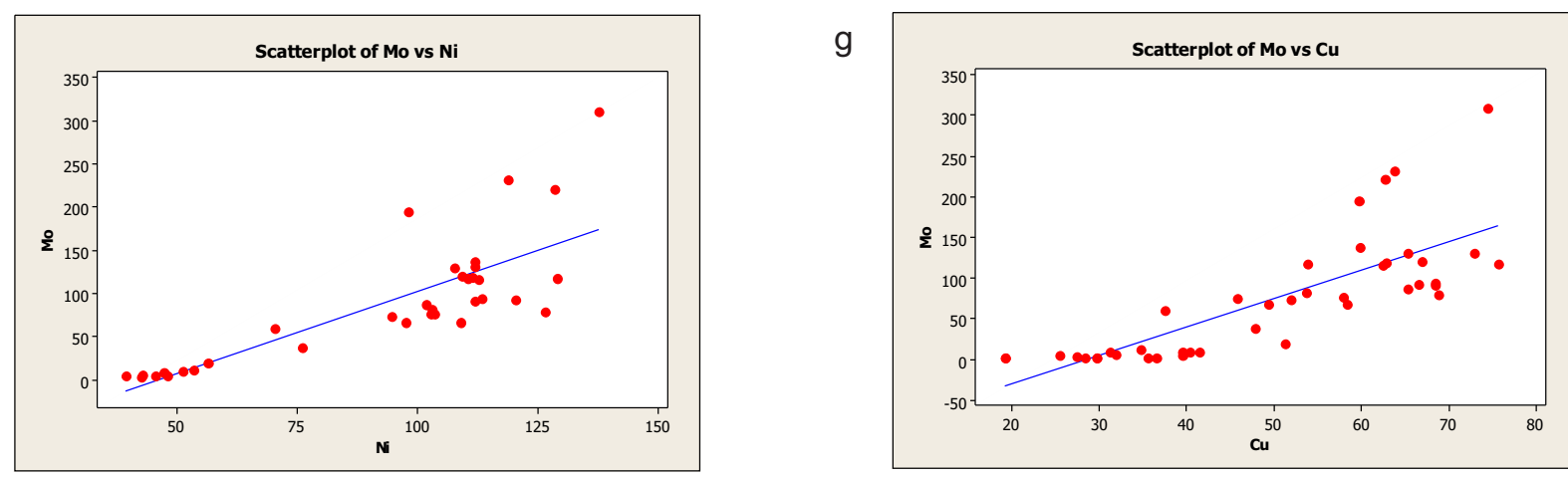

g
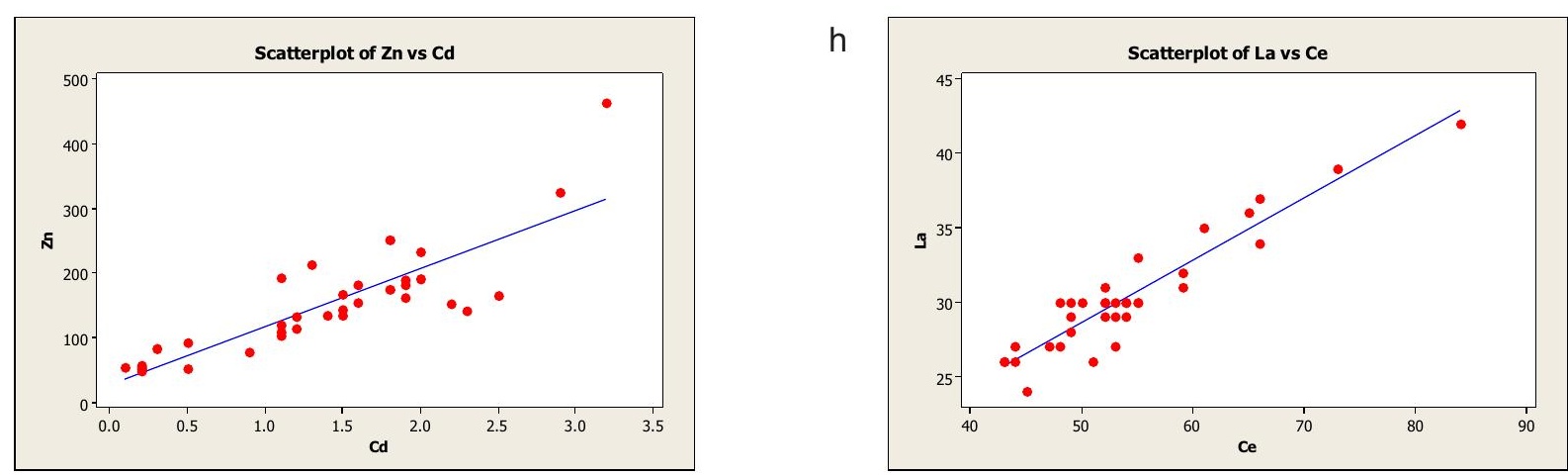

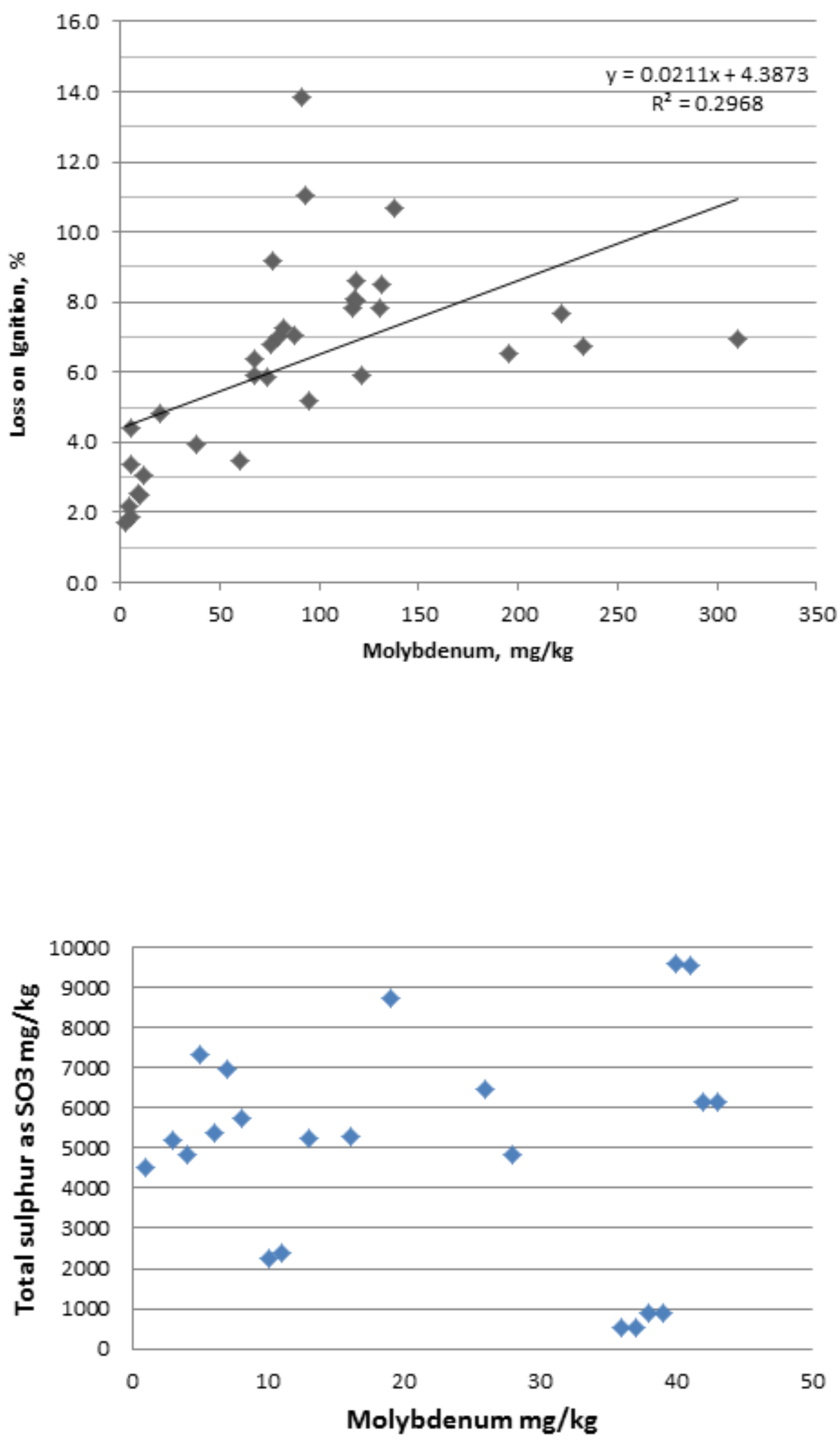
Rock data Dendrogram

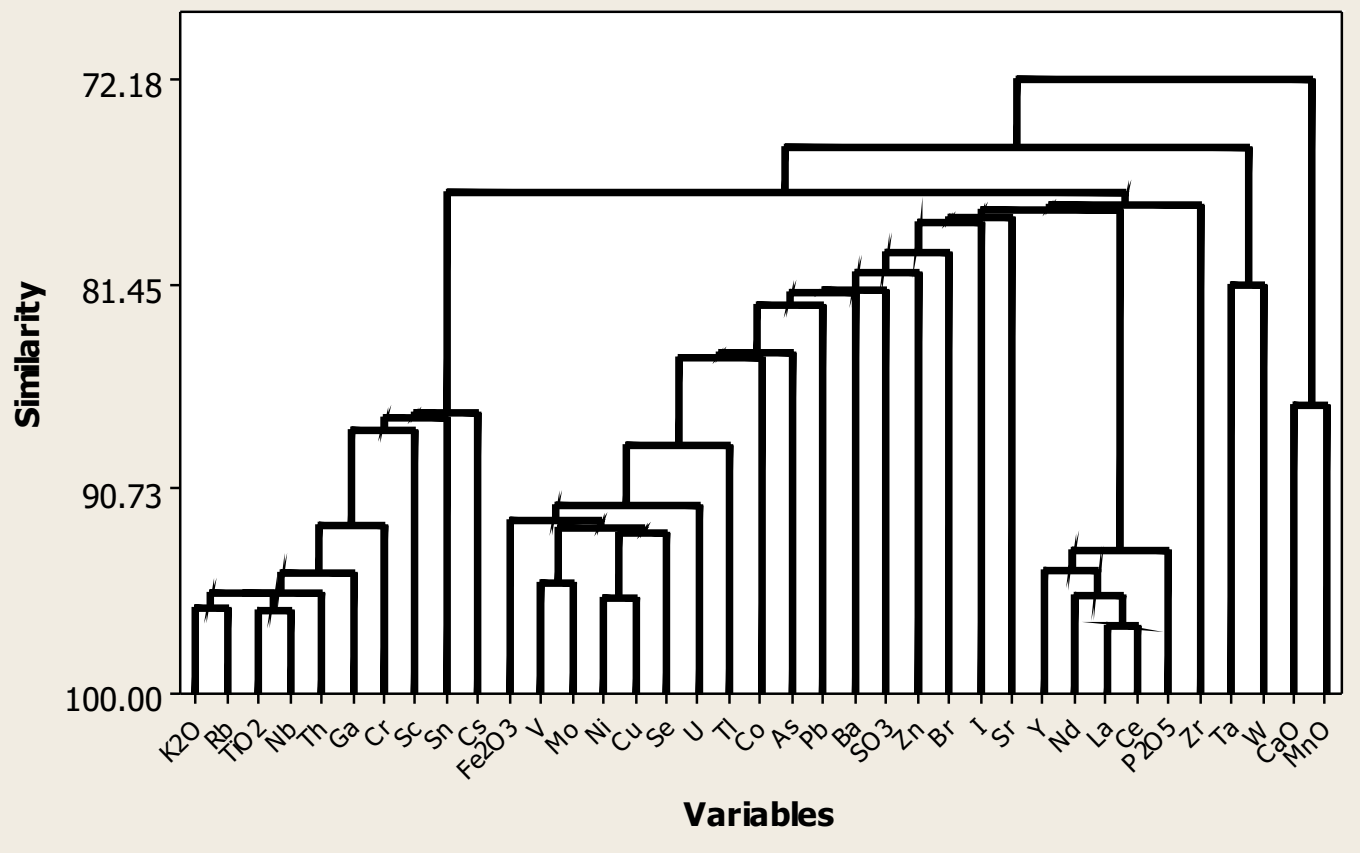




\section{Soil data Dendrogram}

Single Linkage, Correlation Coefficient Distance

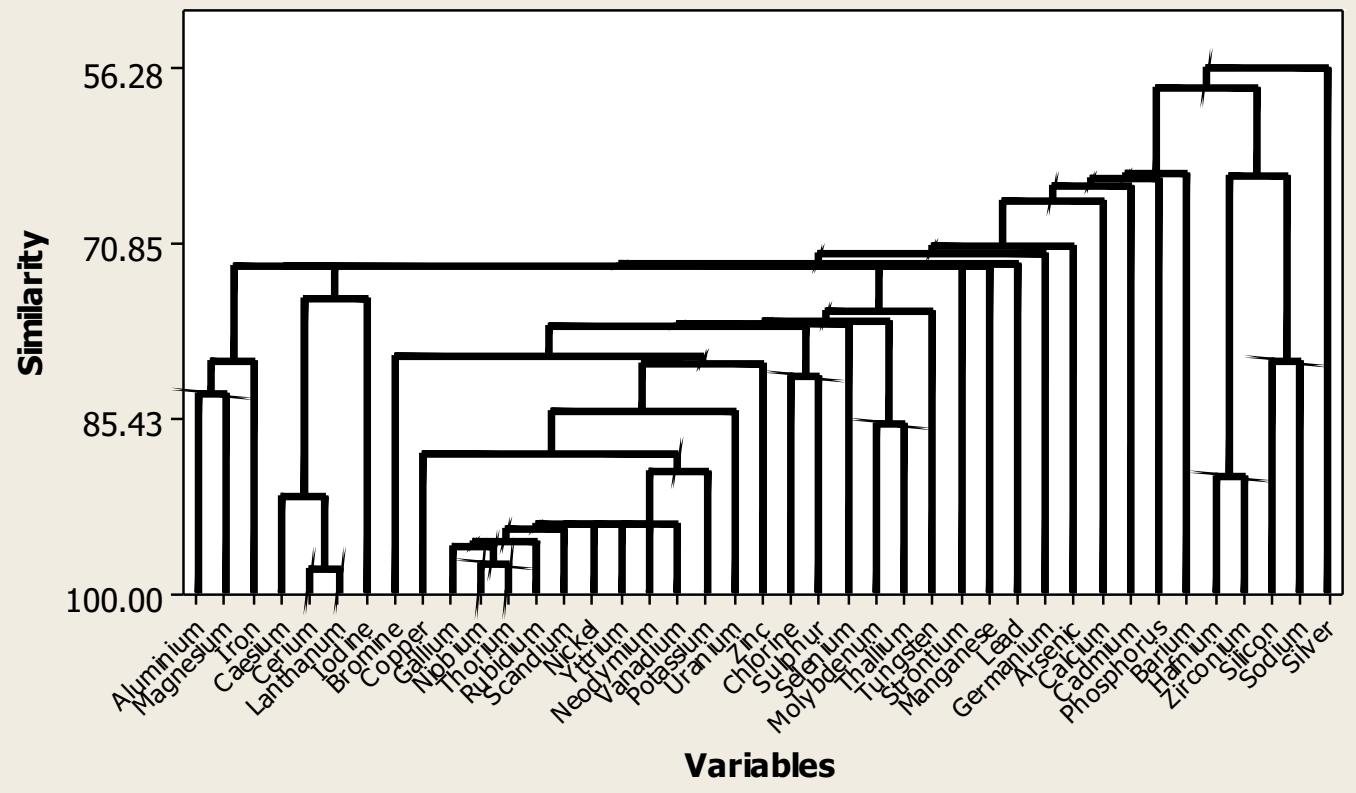




\section{Stream sediments Dendrogram}

Single Linkage, Correlation Coefficient Distance

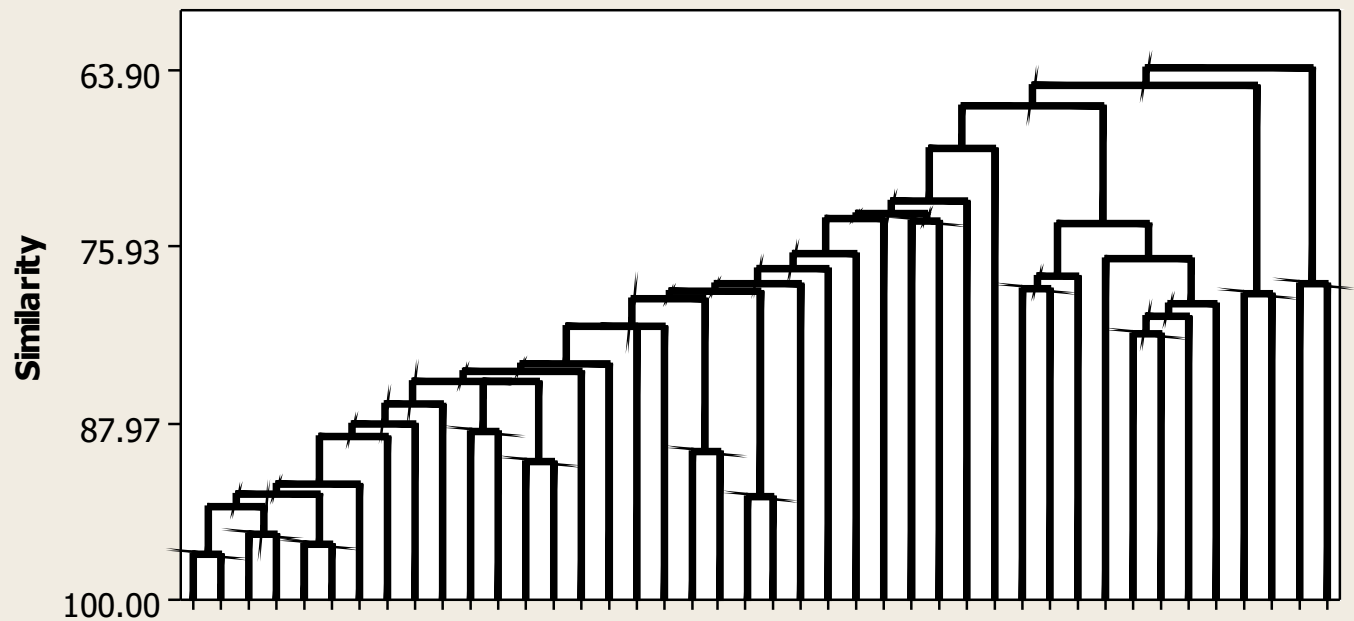

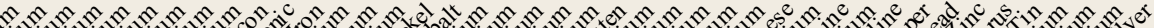
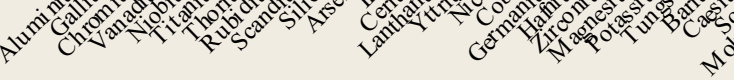

Variables 

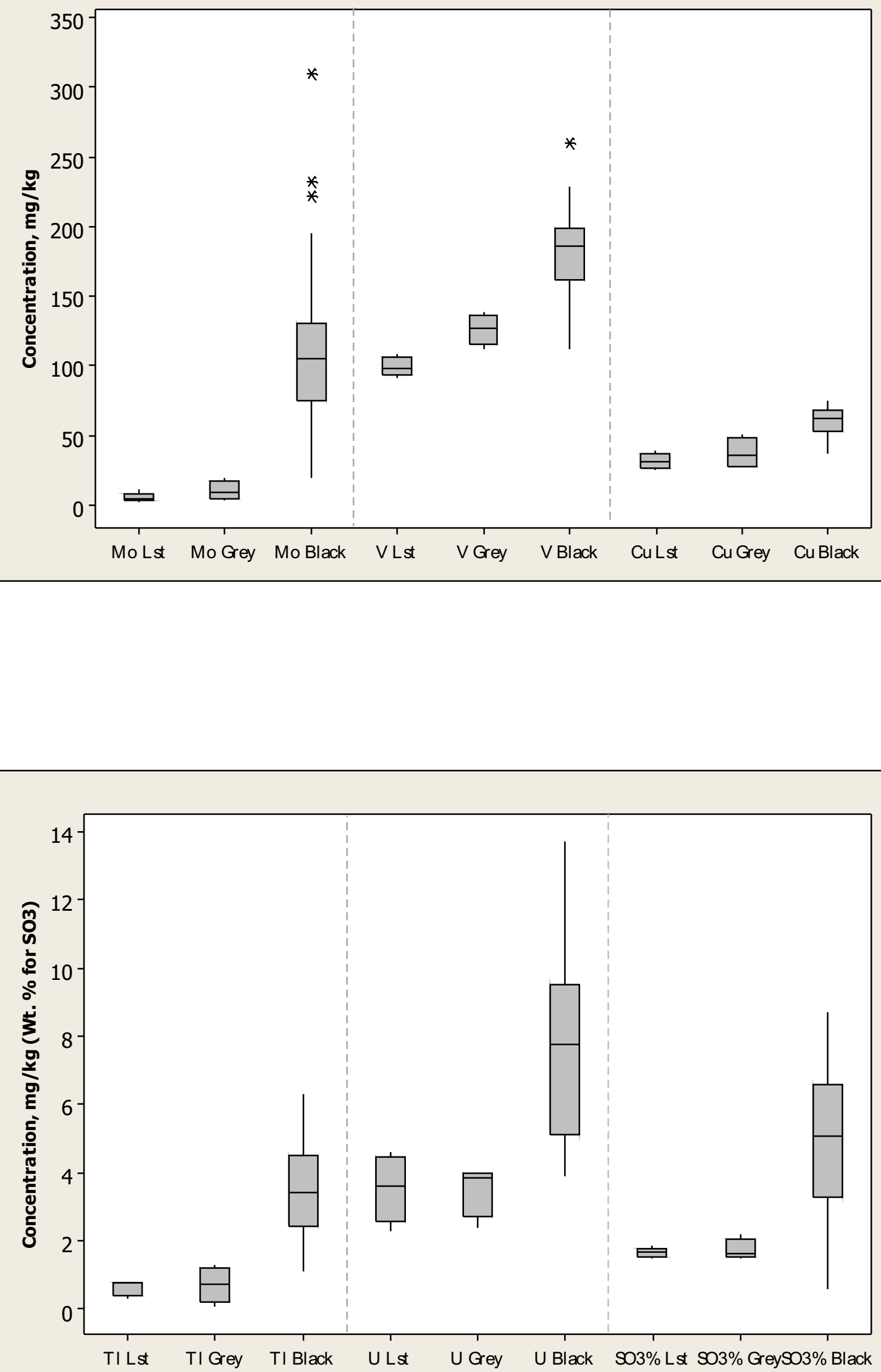


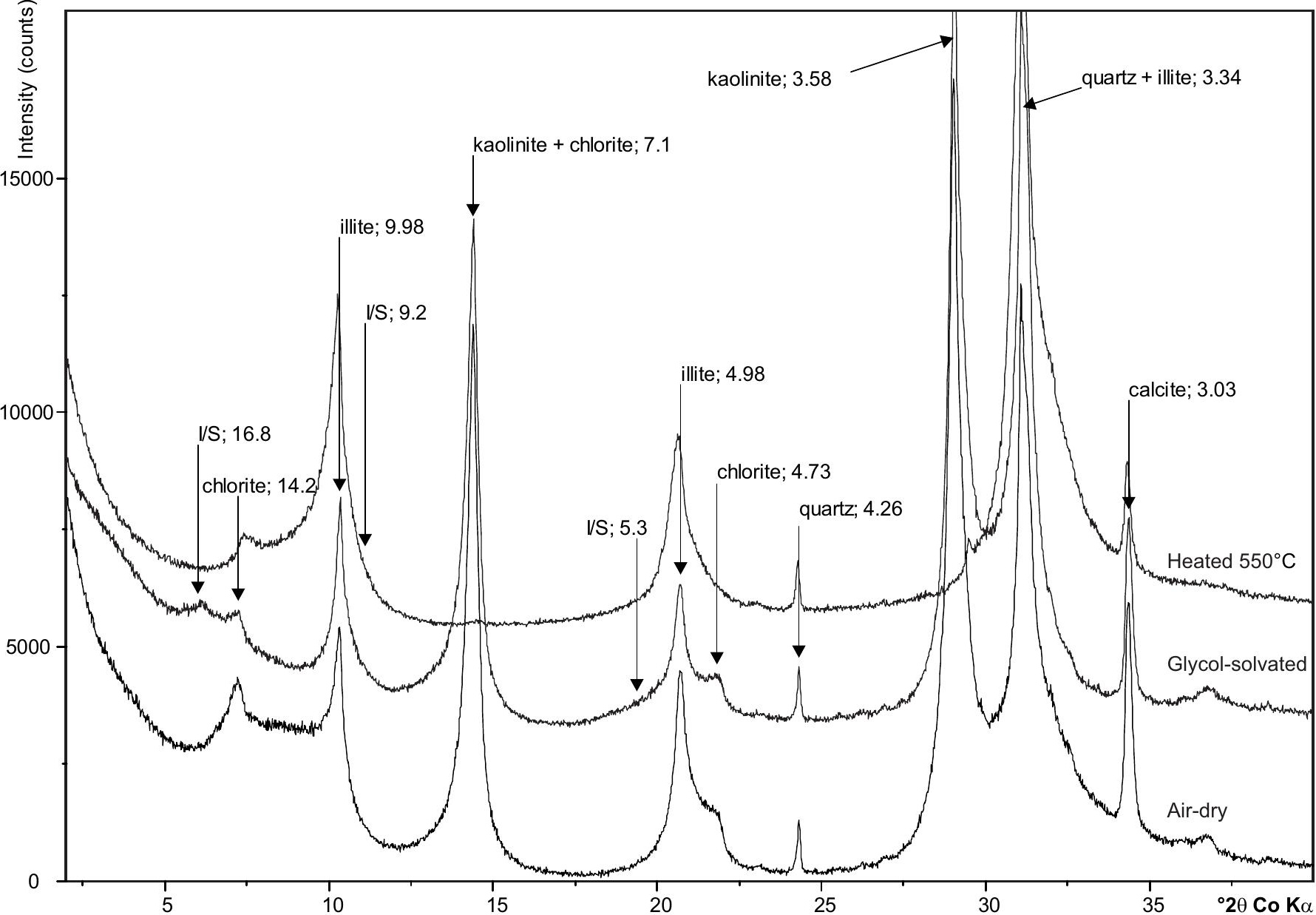

